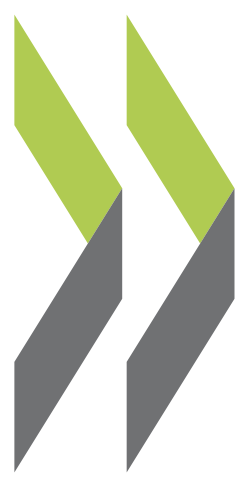

SIGMA Papers No. 21

Promoting Performance

and Professionalism

OECD in the Public Service 
Promoting Performance and Professionalism in the Public Service

SIGMA Papers No. 21 


\section{THE SIGMA PROGRAMME}

SIGMA -- Support for Improvement in Governance and Management in Central and Eastern European Countries -- is a joint initiative of the OECD Centre for Co-operation with the Economies in Transition and the European Union's Phare Programme. The initiative supports public administration reform efforts in thirteen countries in transition, and is financed mostly by Phare.

The Organisation for Economic Co-operation and Development is an intergovernmental organisation of 29 democracies with advanced market economies. The Centre channels the Organisation's advice and assistance over a wide range of economic issues to reforming countries in Central and Eastern Europe and the former Soviet Union. Phare provides grant financing to support its partner countries in Central and Eastern Europe to the stage where they are ready to assume the obligations of membership of the European Union.

Phare and SIGMA serve the same countries: Albania, Bosnia-Herzegovina, Bulgaria, the Czech Republic, Estonia, the Former Yugoslav Republic of Macedonia, Hungary, Latvia, Lithuania, Poland, Romania, Slovakia and Slovenia.

Established in 1992, SIGMA works within the OECD's Public Management Service, which provides information and expert analysis on public management to policy-makers and facilitates contact and exchange of experience amongst public sector managers. SIGMA offers beneficiary countries access to a network of experienced public administrators, comparative information, and technical knowledge connected with the Public Management Service.

SIGMA aims to:

- assist beneficiary countries in their search for good governance to improve administrative efficiency and promote adherence of public sector staff to democratic values, ethics and respect of the rule of law;

- help build up indigenous capacities at the central governmental level to face the challenges of internationalisation and of European Union integration plans; and

- support initiatives of the European Union and other donors to assist beneficiary countries in public administration reform and contribute to co-ordination of donor activities.

Throughout its work, the initiative places a high priority on facilitating co-operation among governments. This practice includes providing logistical support to the formation of networks of public administration practitioners in Central and Eastern Europe, and between these practitioners and their counterparts in other democracies.

SIGMA works in five technical areas: Administrative Reform and National Strategies, Management of Policy-making, Expenditure Management, Management of the Public Service, and Administrative Oversight. In addition, an Information Services Unit disseminates published and on-line materials on public management topics.

\section{Copyright OECD, 1997}

Applications for permission to reproduce or translate all or part of this material should be made to: Head of Publications Service, OECD, 2 rue André-Pascal, 75775 Paris Cedex 16, France.

Views expressed in this publication do not represent official views of the Commission, OECD Member countries, or the central and eastern European countries participating in the Programme. 


\title{
FOREWORD
}

This is a report on human resources management practices in the public administrations of four central and eastern European countries: Albania, Estonia, Hungary and Poland. The report is based on information from 1996. Since then significant changes have occurred in at least two of the countries. In Poland a new Civil Service Act came into force in January 1997 (certain provisions came into force 30 days after the Act's promulgation); and in Albania the current situation in the administration is difficult to assess due to recent political upheaval. When this report was prepared in 1996, Albania, Estonia and Hungary all had civil service laws in force, while in Poland the1982 Act on Civil Servants still regulated employment in the state administration.

The report's purpose is to determine to what extent the implementation of a specific law for employment in the administration would lead to significant changes in personnel management or in the preconditions for management, selection and promotion of staff. This report is therefore about public personnel management systems, management procedures and management practices and how they either support or hinder professionalism and appropriate conduct. To a certain extent it is also about the legislation and institutions as well as the training necessary to promote suitable civil service behaviour.

The study was based on a common guideline document developed together with experts from the four countries. These experts are Odeta Dibra, Lawyer, Albania (now with UNESCO); Professor Georg Sootla, Tallinn Pedagogical University, Estonia; Istvan Borbiro, Lawyer, Jutasi \& Partners, Hungary; and Wojciech Marchlewski, Co-operation and Partnership, Poland. The four experts used the guideline document as a reference tool for conducting interviews in the administrations of their countries and for reporting their findings.

The report, which has been cleared with the four governments, was prepared by Marie-Christine Meininger, Deputy Director of Research and Publications, International Institute for Public Administration (Paris), and Professor Alain Claisse, University of Paris 1. They also co-ordinated the project and the work of the four experts. This publication is also available in French under the title Promouvoir l'efficacité et le professionnalisme dans la fonction publique (Documents SIGMA : $N^{\circ} 21$ ).

\author{
SIGMA-OECD, 2, rue André-Pascal, 75775 Paris, Cedex 16, France \\ Tel. (33.1) 45.24.79.00; Fax (33.1) 45.24.13.00 \\ e—mail: sigma.contact@oecd.org; http://www.oecd.org/puma/sigmaweb
}




\section{TABLE OF CONTENTS}

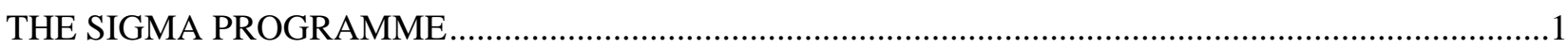

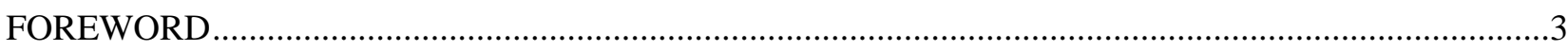

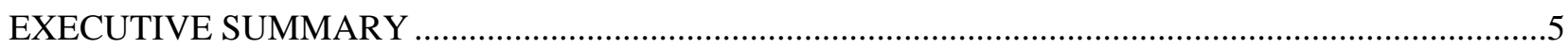

1. INTRODUCTION

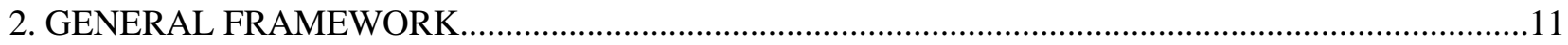

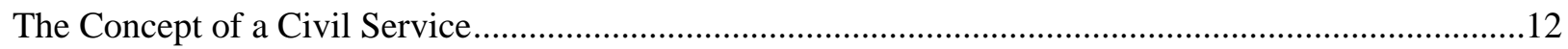

Size of the Civil Service and Distribution of Staff ............................................................................15

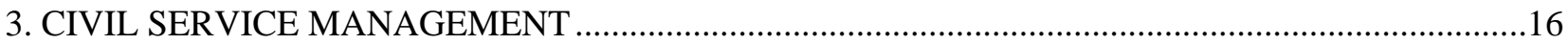

Ministerial Autonomy and the Difficulty of Co-Ordinating and Implementing a National Policy for

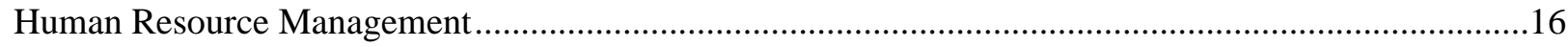

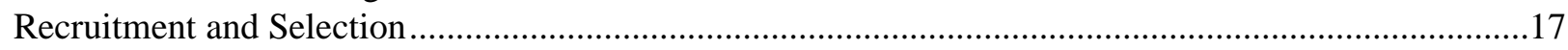

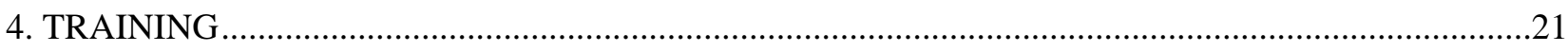

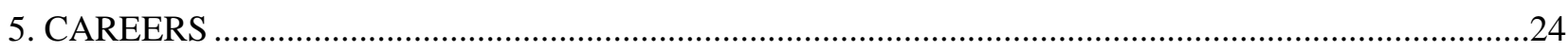

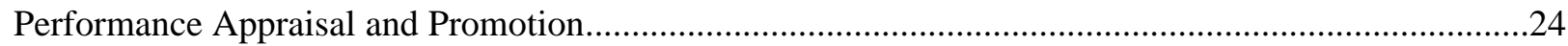

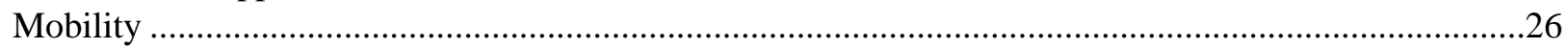

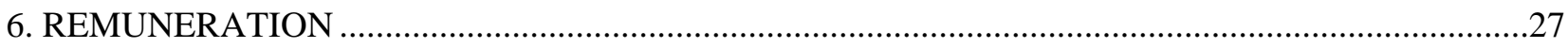

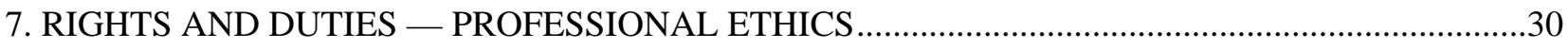

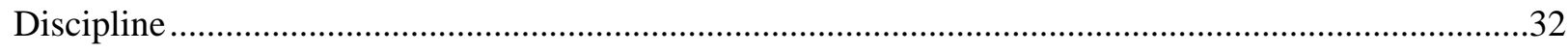

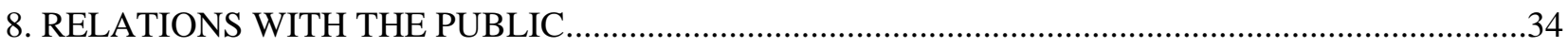

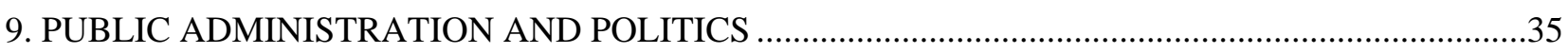

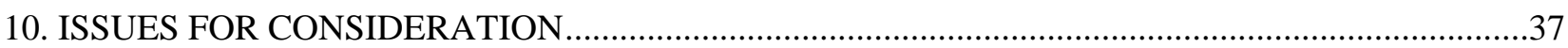

10.1. Principle and Establishment of a Statutory Framework for the Civil Service ................................37

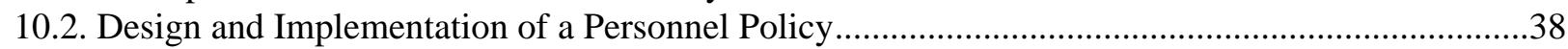

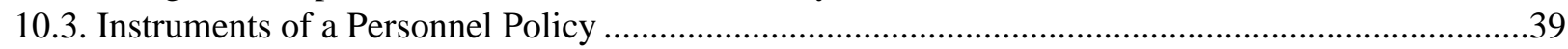

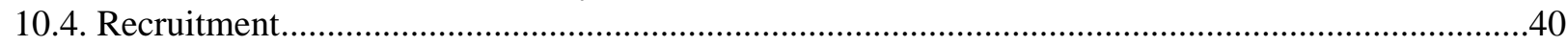

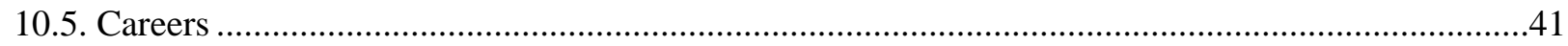

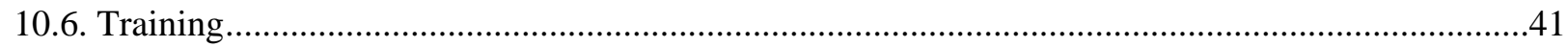

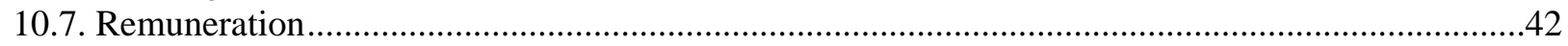

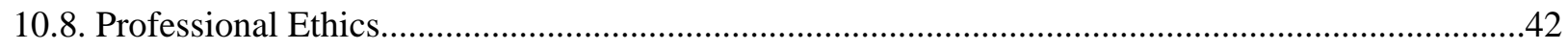

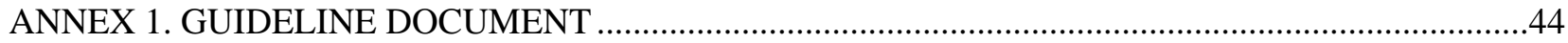




\section{EXECUTIVE SUMMARY}

A professional and efficient public administration implies competent, motivated and impartial civil servants working in a system dedicated to serving the public interest. While it may be relatively easy to draw the profile of a merit-based civil service in conceptual terms, it is much more difficult to define the ways and means of putting such a civil service into place. Although countries of the central and eastern European region for the most part have institutions in place, significant shortcomings exist in civil service legal frameworks, co-ordination structures and management.

This report, based on cases studies in Albania, Estonia, Hungary and Poland, defines concrete management areas and and makes recommendations for consideration by those responsible for reforming a country's public administration or for managing a public institution. These recommendations cover: the principle and establishment of a statutory framework for the civil service; design and implementation of a personnel policy; instruments of a personnel policy; recruitment, training, remuneration and career development systems and professional ethics.

Regarding a statutory framework for the civil service, the need for simple rules which can be immediately applied is universally recognised. All of the four countries studied have adopted a statutory framework for the civil service. However, these rules laid down in law must be recognised and accepted by all the parties concerned and be transformed into management practices.

The lack of a co-ordinating, advisory and implementing body for personnel management has an adverse impact on career management. It can undermine efforts made to make the civil service both more professional and more efficient. A minimum level of co-ordination could help to prevent conflicting regulations or policies from being introduced by individual ministries. Co-ordination could include the implementation of priorities set at the national level, the matching of resources to objectives and the monitoring of personnel management.

Irrespective of the role given to the co-ordinating body, the role of the personnel directorates within each ministry is crucial. When such directorates are given the authority, stability and resources required to exercise their functions, human resources are managed with greater rigour and the influence of political factors or personal networks is significantly reduced.

One instrument to harmonise management and compliance rules consists of the creation of a single staff register. Computerised management is the most functional method, as it also makes it possible to share the register.

Providing information on the rules governing post and career management can be viewed as a highly positive measure, making it possible to attract larger numbers of applicants. One aspect of this information is the publication of vacancy notices, which contributes substantially to the improvement of recruitment exercises.

The professionalism and efficiency of the administration depend not only on the quality of recruitment, but also on the organisation of career development. The establishment of a common framework applicable to different administrations and which sets a hierarchy of functions, grades and career development has a clarifying and harmonising effect. Career development based on the principle of rewarding merit constitutes the central element for professionalising the civil service and motivating its officials. In order to reward merit, it is first necessary to put in place an evaluation system which makes it possible for 
decisions relating to career development to be based on a fair assessment of qualifications and performance, thereby ensuring the promotion of those officials whose competencies can be objectively recognised.

In the area of training, progress made could be built upon further by introducing an overall policy that takes account of both immediate requirements and longer-term needs. Matching the provision of training to the real needs of administrations might only require a fairly basic mechanism (consultation, surveys or other) to ensure a dialogue between those providing and those requesting training.

On the subject of professional ethics, a cautious and pragmatic approach needs to be adopted in drawing any lessons from the experiences of the four countries studied. Regulations that are too sophisticated have proved to be ineffective. A system of sanctions, but especially a firm resolve to implement such sanctions, is essential.

Most administrative systems have one major characteristic in common: the problem of matching legislative texts with practices, and the need to narrow the gap between the two in order to ensure that the administration, and more generally the rule of law, functions properly.

Reforms will stand a greater chance of success if efforts can be successfully combined and if there is:

- a clear and continuous political resolve, expressed at the highest level, to ensure that the initial project does not lose momentum;

- widespread involvement of public officials at all levels of the hier archy, in order to reduce the risk of misunderstanding or resistance to change;

- support from the public, as reforms will be more willingly accepted if the public feels that, in more or less the long term, it will benefit from them; and

- assistance from the international community and from multilateral and bilateral co-operation organisations, whose ability to provide intellectual and material support for the reforms will be even greater if the objectives and means of achieving those objectives have been clearly defined.

This SIGMA paper is available in English and French on the SIGMA Web site at http://www.oecd.org/puma/sigmaweb. 


\section{INTRODUCTION}

Among the administrative reforms undertaken in central and eastern European countries since the beginning of transition, the adoption of a statutory framework for the civil service, following the example of western European countries, was seen by many as a prerequisite for the establishment of a professional civil service, based on merit and capable of serving the public interest competently and effectively.

Although the statement of such an objective may appear simple, none of the words making up that statement is self-evident. Behind the statements of principle, numerous ambiguities remain.

Historically, the development of a permanent administration, staffed by officials recruited on the basis of their qualifications and in accordance with common rules, rather than by political appointment or heredity right, is a relatively recent phenomenon in Europe. A permanent civil service serves to satisfy this requirement of professional qualifications and neutrality.

The notion of a career-based civil service is to be understood in its first meaning, as opposed to the concept of a job-based civil service. The career system which predominates within the European Union may be described as a combination of several elements: early recruitment for life with a view to pursuing a career within the public administration; a hierarchical progression with successive stages and conditions for progress determined by rules and regulations; the assumption that officials will hold a series of posts in the course of his/her career. This system, which goes hand in hand with the assertion of the distinctive nature of public service, is generally opposed to a job-based system ${ }^{1}$ in which civil servants are recruited in principle with a view to doing a specific job without having the right to a career. In the latter system, the civil service is broken down into a large number of jobs. A career-based system is generally viewed as a "closed system", since it precludes or severely limits the possibility of entry in mid-career. The second system is more "open" to the recruitment of officials who have already accomplished a portion of their professional life elsewhere.

However, these systems are not mutually exclusive. A review of existing civil services in Western Europe does not reveal any major divergences between a career system and a job system. Neither system can be considered to produce better results, and the choice in favour of one system or the other must be made on the basis of the country's specific situation.

In the career system there is not always an absolute guarantee of security of employment, and a job system bears many similarities to a career system (especially noteworthy is the fact that redundancy is generally subject to more or less restrictive conditions). However, the main difference between the two lies in career development. Admittedly, it is possible to build a career in a job system by holding a series of different posts. However, recruitment is valid for a specific job and in some countries offers salary increases based on seniority alone. Any promotion or advancement implies in those countries a new recruitment exercise.

1. See Claisse, A., Meininger, M.C., Fonctions publiques en Europe, Montchrestien, Paris, 1994, 158 pages. 
The implications of the aspiration of central and eastern European countries to establish career-based civil services needs to be examined in greater detail. To begin with, a distinction needs to be drawn between the creation of a career civil service and the enactment of a statutory framework. The guarantees for career development can in fact just as readily be provided by a system of collective agreements, and the existence of a statutory framework as such does not prejudge either the content of the rules laid down (which could in part be taken from the Labour Code) or the implementation of such rules.

Next, the concept of a neutral civil service based on merit needs to be clarified. It implies the existence of a corps of officials recruited and promoted on the basis of their professional qualifications and serving the public interest, as it is defined by law.

The principle of merit relies on the recognition, in both symbolic and material terms, of the value of qualifications and know-how.

Neutrality may be understood as meaning neutrality with regard to not only the political authorities but also private interest groups. It goes hand in hand with impartiality. Political neutrality — in either absolute or relative terms - precludes neither the subordination of the administration, in the exercise of its duties, to governmental authorities, nor the possibility that political appointees surround themselves with close collaborators in whom they have confidence. What it does imply, on the other hand, is a separation between political and administrative levels, and the absence of interference in the form of partisan concerns in the management of careers. The level at which this separation should be made can obviously vary widely depending on circumstances and from one country to another.

The establishment of a career civil service based on a legal status has constituted the main approach adopted in Europe for the creation of a professional and efficient civil service. It has nevertheless not proved to be an easy process, as this study will attempt to show.

SIGMA has undertaken this study from two perspectives:

- as an in-depth survey in several countries to determine the conditions in which civil service systems actually function, that is to say by going beyond the written texts to determine the methods and personnel management practices followed, the difficulties faced and the progress achieved;

- as a means of drawing conclusions regarding the basic issues that seem to merit special attention.

Four countries were selected on the basis of their diversity and representativeness in relation to the group of countries comprising Central and Eastern Europe. These four countries are each at different stages of administrative development.

Hungary (10 million inhabitants) has a long parliamentary tradition. The 1989 Constitution and the elections in the spring of 1990 marked the return to a pluralist democracy. After reforming its institutions ${ }^{2}$, the country is now giving priority to establishing a market economy based on private property.

Administrative reforms, and in particular the adoption of a statutory framework for the civil service, were undertaken from the very beginning of the transition, and the task of overseeing this process is entrusted to a commissionership responsible for modernising the administration. Hungary benefits from a

2. For each of these four countries, see Public Management Profiles - SIGMA Countries (Revised Edition 1995), SIGMA, Paris, 1995, 266 pages. 
long-standing administrative tradition and has always been distinguished, even during the communist period, by a concern for pragmatism, which has led to gradual adjustments in the administrative area. Hungary has the advantages of a fairly sophisticated legislative and regulatory system and a satisfactory general level of top officials.

Poland, the largest and most populated of the four countries selected (almost 40 million inhabitants), had been deeply marked by the period of Soviet domination but has since made a clean break with the former rules in an endeavour to promote a liberal administration. Following a series of political events, the country held its first free elections in 1991, and as from 1992 has carried out constitutional reforms as well as mass privatisations. The government's long-term strategy ("Strategy for Poland"), approved by the Parliament in 1994, refers inter alia to the reform of the civil service, which has been identified as a prerequisite for economic and social reforms. Poland has at its disposal highly-qualified top officials, but not yet in sufficient numbers to meet its needs.

Estonia, the smallest of the four countries in terms of size and population, regained its independence in 1991 after fifty years of occupation. The new Constitution was adopted in 1992. Estonia is a unitary state and parliamentary republic of 1.5 million inhabitants, noteworthy for the high proportion of Russian-speakers (approximately a third of the population). The 1995 Law on Citizenship sets out the relatively stringent instructions for their acquiring Estonian nationality. Economic and administrative reforms have been undertaken at an accelerated pace (privatisations, reform of government structures, public management, social protection, etc.). This is a country in the full phase of institutional reconstruction, with greater or lesser progress being achieved depending on the sector, which gives a contrasting shape to the administrative system. Estonia also has a long-standing tradition of education, culture and administration, which was widely suppressed during the Soviet period.

Albania ( 3 million inhabitants) is the country which has experienced the greatest difficulties, as recent events have shown. The transition from a system which was totally turned in on itself to the construction of an administration capable of dealing with a market economy (introduction of normative rules, recruitment of qualified top officials, training of officials in the basic principles of management and administration, etc.) has been slowed down due to the limited availability of human and financial resources. Albania is a parliamentary republic whose institutions have been defined by law on the basis of the main constitutional provisions of 1991, subsequently amended on several occasions. The first free elections were held in March 1992. Work has begun on the privatisation of the economy and administrative reforms have focused on central and local structures, procedures and the civil service. However, the serious riots of 1997 raised doubts about the state authority and perturbed the entire administrative and management system, making it even more difficult to put in place a functioning administration.

This study on the four countries was carried out in several stages between spring and autumn 1996.

The first stage consisted in drawing up a detailed guideline document (attached as Annex 1) relating to both written texts and practices (statutory framework, staff numbers, recruitment, career management, rights and duties, etc.).

The next step was to identify correspondents in each of the countries. These correspondents were chosen on the basis of not only their academic knowledge but also their practical experience and objectivity. They were given the task of evaluating the guideline document with regard to the distinctive characteristics of their country and of carrying out the survey in several sectors (four per country, chosen from among finance, interior, labour, education, health, commerce and industry), selected according to their representativeness and the availability of information. 
National reports were then drawn up by each of the correspondents and presented in July 1996. On the basis of these reports, the project co-ordinators drafted a first synthesis report, whose contents and conclusions were reviewed in the course of a one-day working meeting with the national correspondents and SIGMA representatives. The combination of all these elements has resulted in the present document. This report does not take into account the new Polish Civil Service Law of 5 July 1996. Moreover, the recent events in Albania have rendered null and void some of the observations concerning its administration.

The civil service management systems, procedures and practices in the four countries studied exhibit a number of characteristics which this report attempts to identify and analyse. The use of common guidelines to examine each of these countries has made it possible to compile data which can then be used for a horizontal and comparative approach, highlighting the common features in each of the civil service systems as well as their specific characteristics. On this basis an overall assessment can be attempted, putting forward a number of issues for consideration, with a view to improving the functioning of procedures and practices, in a pragmatic and realistic way. 


\section{GENERAL FRAMEWORK}

It is important to bear in mind the significant role played by tradition, cultural background, political and administrative history, and external influences in each of the four countries studied. These factors act in concert with the conditions governing the process of transition; the situation and degree of development of the private sector, as well relationships with the administration and society, have far-reaching impacts on institutions and behaviour.

There is a relationship between the degree of development of the society and that of the civil service, and this can lead to a wide variety of situations.

Transition must be viewed as an evolutionary process, with rapid changes and necessary rest periods required in order to "digest" reforms. All of the countries studied have made considerable efforts and the transition process possesses its own internal momentum. However, the challenges are not the same for all countries. While for some countries it is really a question of setting up a civil service system, for others it is more to pursue reforms already underway, with a view to improving this system.

The first issue that arises is how to deal with the administrative machinery left by the previous regime. The transition period in all four countries studied has not led to a total upheaval of structures and personnel already in place. Admittedly the changes have been greater in Albania, where the traditionally strong politicisation of the administration led to numerous departures, than in Hungary, where for the most part there has been no replacement of staff recruited prior to transition. However, rather than resorting to spectacular purges, efforts have been made to transform the existing system through cutbacks and restructuring.

In Albania, the renewal of public administration personnel was based on a revision of labour legislation: formerly this only allowed employees to be dismissed for reasons of professional negligence or violation of regulations or legislation. On 30 April 1992, Parliament passed an amendment to the Labour Code of 12 December 1991, allowing heads of services to assign their employees to other jobs. In the absence of any position corresponding to the qualifications of an official, the social services became responsible for the official for a year, after which time he/she was dismissed. A large number of officials were dismissed on this basis between 1992 and 1996: most of them were dismissed during the first few years because they did not have the required qualifications for a professional kind of job or because they had been recruited for political reasons in the previous era. The 1991 amendment was rescinded on 22 February 1996, shortly before the end of the legislative term.

In Estonia staff reductions have taken place. These have not been based solely on political criteria, but also on age, qualifications, and particularly knowledge of Estonian.

In Poland, the abolition or reorganisation of a number of departments led to staff cutbacks. This was a question of eliminating overstaffing or using it as an opportunity, especially during the 1990-92 period, to dismiss officials tainted by their close links with the former regime. These reorganisations provided opportunities to get rid of certain officials without incurring financial consequences. At one point, heads of departments were asked to designate 10 per cent of their staff as superfluous to requirements. Due to 
the automatic aspect of this operation, it affected equally overstaffed departments and growing departments, such as the office responsible for issues related to European integration. In a number of cases, the officials dismissed were subsequently reinstated by the labour jurisdiction. In the Ministry of National Education, for example, which had dismissed 60 per cent of its staff, nearly all of the heads of department dismissed at that time have now been reinstated.

By and large, the four countries studied remain marked by the legacy of the communist era, when the private sector was weak or non-existent, and all wage earners were paid out of public funds and were subject to uniform labour legislation. During the initial years of transition many reforms had to be carried out within a very short space of time. An empirical approach has therefore been adopted in efforts to establish a professionalised civil service based on specific legislation. However, there is some doubt as to whether these efforts are founded on a clear understanding of the goals pursued and the means to attain them. In each country, the need for specific legislation to guarantee the neutrality, stability and efficiency of a corps of professional civil servants has been accepted in principle. However, everyday practice is sometimes at variance with the spirit of such legislation. Vestiges of earlier bureaucratic practices still remain and individual administrations, or even departments, are sometimes given free rein to manage their staff in accordance with local conditions and ad hoc power relationships.

In the four countries studied, there is a law or set of laws which can be compared to a statutory framework for the civil service: in Hungary, Act No. XXIII, since 1992; in Estonia, the Act of 25 January 1995; in Albania, the Act of 21 March 1996. The last two texts are in any case too recent to pass judgement on their effectiveness. In Poland, the legislation in force at the time this report was written was the Act of 1982, which had laid the foundations for a civil service (hierarchical system of grades, salary scale, advancement by seniority and merit). A new law has recently been adopted (Law of 5 July 1996), and is due to be implemented progressively in stages, but it was not possible to take into account its implementation at the time this report was written. In general, the existence of a civil service law leaves room for a certain diversity in the legal status of those affected, particularly in the case of Hungary.

The adoption of a civil service law results from a need for a clarification of the respective roles of central government, dependent public bodies or agencies, regional authorities and public sector enterprises. The concerned officials themselves have been calling for such a clarification of their working conditions, rights and duties (cf. Estonia and Albania). However, the implementation of legislation granting a civil service status is only just beginning and, as with any major reform, particularly in the context of transition, it gives rise to difficulties in application and attempted adjustment. For example, in Hungary an amendment has introduced a degree of flexibility in relation to wages for bodies which have independent funding; a complete revision of the 1992 Act is on the agenda, aimed especially at increasing mobility within the civil service. In Estonia, the conception of the Act of 25 January 1995 was regarded as too theoretical, and it was amended in December of the same year in order to resolve practical difficulties, in particular budgetary problems raised by the vague and sweeping nature of its definition and its scope of application. Implementation of the Act would require numerous texts of secondary legislation.

In general, central and eastern European countries now have a double concern: to continue with the formulation of a new legal framework based on the principles of equality and merit, and to apply the existing legislation effectively in order to strengthen the rule of law and public service efficiency.

\section{The Concept of a Civil Service}

In some countries civil servants represent the majority of officials employed by the public authorities; in others, they only account for a small proportion of the total staff of administrations (10 per cent in 
Poland). These differences reflect major divergences with regard to the concept itself of the civil service, which are obviously attributable to the differing historical traditions as well as to the different political, economic and social contexts in which reforms have been drawn up. Each of the four countries therefore defines the term "civil servant" in a different way, and in several of these countries even the legislative texts are unclear as to its precise scope. While it is therefore important to determine the scope of application of the statutory framework applicable to the civil service, it needs to be borne in mind that there are still a large number of officials who fall outside the scope of this definition and whose qualities and professionalism have just as much of an impact on the efficiency of the administration.

In Hungary, there are primarily five categories of public officials: civil servants, public service employees, workers and a fourth, fairly disparate, category whose statutes are defined in specific texts:

- Under the provisions of Act XXIII of 1992, civil servants are defined as officials exercising managerial, decision-making, legislative or implementation functions or entrusted with particularly important tasks within the public administration bodies (listed in the annex to the law). This category represents only 12 per cent of all public personnel;

- Officials responsible for providing services (teachers, officials working in health services or other services managed mainly by local authorities);

- "Blue collar" workers subject to the Labour Code;

- Officials wearing a uniform and responsible for ensuring obedience to the law: the police, customs officials, firemen, and members of the armed forces. Each of these groups is governed by specific legislation which takes account of their specific tasks and conditions of service.

- A last category of "specialists" is made up of judges and other legal professionals.

The main rules governing these various categories of officials are identical, although the conditions relating to recruitment, career development, remuneration, and their respective rights and duties may vary.

In Estonia, the scope of application of the civil service law had to be narrowed, from 1993 to 1995, since the budget had not provided for the expenditures corresponding to the payment of benefits associated with the new civil servant status.

Under the terms of the civil service law passed on 25 January 1995 in Estonia, the civil service is defined as employment by the state or by an administrative agency, that is to say a department funded under a (central or local) public budget and exercising "public authority". The law makes a distinction between three types of public officials: top officials appointed to a state body or local authority; support staff, who are employed under contract; and temporary personnel, who are appointed or recruited under fixed-term contracts. The category of "top officials" is clearly distinct from the others and the corresponding definition in the legislation assigns them managerial or planning functions.

It is significant that in Estonia the basic concept of the civil service has evolved since the draft civil service law of 1993. Originally, the text did not contain a clear and workable definition. The definition of what constituted the civil service was fairly broad and its application to all officials deemed to be covered by the law would have made all these officials subject to the salary scale and eligible for a number of financial benefits, including bonuses for which no provision had been made in the budget. Protests by the Ministry of Finance and State Chancellery led to a reduction in the scope of application of the law. Amendments enacted on 20 December 1995 set out a list of administrative bodies authorised to employ civil servants. The consequence of this definition of civil servants by reference to a list of bodies 
authorised to employ them is that identical functions can be performed either within the framework of the civil service or not, as the case may be. As a result, the entire sectors of health and social security are excluded, and officials carrying out comparable functions may have a different status, depending on whether they belong to one of the public authorities specified in the legislation. For practical reasons a more restrictive definition was adopted. The scope of application of the law was thus limited to specific bodies and made contingent upon employment by one of the public authorities specified by the law-makers.

At the same time, it should be noted that the Estonian civil service law applies to officials appointed by the government or by a minister, the secretary of state, general secretaries in ministries, deputy general secretaries, general directors of agencies and inspection services, and governors of counties. Only the holders of elected positions are excluded from its scope of application.

Furthermore, it must also be pointed out that even though the civil service is divided into two parts, the central civil service and the local civil service, certain sections of the law are not mandatory for the local civil service and can be considered as recommendations (in particular the provisions concerning allowances, financial benefits, and the official salary scale).

Finally, certain categories of civil servants are subject to specific legislation (police, border guards and prison administrations).

In Poland, the basic criterion for the civil service is appointment by a state authority and assignment to the central administration, a decentralised agency or even a regional administration. This criterion excludes from the scope of the civil service any officials under contract or personnel employed by local authorities. Appointed civil servants constitute approximately 10 per cent of ministerial personnel. Contracted officials are subject to the Labour Code.

In Albania, the Act of 5 April 1996 applies to politically appointed civil servants and to all public officials in central and local administrations. As in Hungary, special categories such as judges, members of the armed forces and the employees of public enterprises are covered by separate legislation. Education and health sector employees do not have the status of civil servants but are subject to the Labour Code.

Thus a more or less restrictive conception of the civil service has been adopted in these four countries. The civil service can be considered as the hard core of the public service, and does not include categories considered to be on the "periphery" of the central administration. The exact nature of these peripheral categories varies from one country to another: technical or operative personnel in Estonia, contractuals and local authority personnel in Poland, non-established public service officials in Hungary, and health and education service officials in Albania and Estonia.

The overall structure of the public service can thus be represented in the form of concentric circles. All categories share certain principles laid down by law, but also have their own specific characteristics depending on their functions and status. In passing from the centre to the periphery, the legal situation becomes increasingly subject to labour law. Nonetheless, the boundaries between these different categories remain blurred and are often determined by circumstances or budgetary constraints, which does not make any clearer the tasks assigned to various types of officials, or more generally the regulatory and planning role assigned to the central administration.

One of the most sensitive aspects, and one to which this report shall return, lies in the distinction between political and administrative functions. Above all, while some functions are clearly defined as being political in nature, the scope of those which in practice are politicised is obviously much broader, as is the 
case in many Western countries. In Albania and Estonia, the new status claims to apply to officials appointed by the government (in the case of Albania the express aim is to ensure greater transparency with regard to their remuneration). In none of the countries studied are recruitment and career development, at different levels, totally free of political influence.

\section{Size of the Civil Service and Distribution of Staff}

Given these differences and uncertainties in the definition of the scope of the civil service, any comparison of numbers is arbitrary and any statistics provided must be treated with extreme caution. Such statistics nonetheless constitute an extremely useful tool for decision-makers and managers. Every encouragement should therefore be given to the development of statistical tools to allow management services to gain a better understanding of staff, their distribution and evolution. 


\section{CIVIL SERVICE MANAGEMENT}

\section{Ministerial Autonomy and the Difficulty of Co-Ordinating and Implementing a National Policy for Human Resource Management}

The weakness, if not total absence, of co-ordinating structures is clearly evident in all of the countries studied. The collapse of the former single or dominant party system left a huge gap in the planning and monitoring of public affairs, which has yet to be entirely filled. The difficulty in achieving a consensus in the political class exacerbates shortcomings in co-ordination and management. While Hungary and Poland have set up reform units at the summit of the government hierarchy to provide leadership and co-ordination in the fields of administration and reform, these bodies have been assigned ambitious tasks but do not possess either the qualitative or quantitative human resources needed to carry them out. As a result, they have had to focus on only a few tasks. In Estonia, the department for the development of state agencies of the Ministry of Finance is responsible for "analysing the activities, development and effectiveness of public bodies" and for "contributing, through the provision of appropriate budgetary resources, to the follow-up of administrative reforms". This department at present is limited to dealing with the financial aspects of personnel training. This situation is encouraging the fragmentation and diversification of management modes between ministries and in some cases even within ministerial department.

As a result, in all four countries studied, ministries and administrative bodies are granted substantial autonomy in the area of human resources management. The extent to which regulations are implemented varies over time and from one ministry to another; it also varies according to the degree to which managers consider them to be properly founded and mandatory. Managers have in fact considerable freedom in implementing regulations (or sometimes in setting them), and it seems that the system does not always provide a counterbalance to possible political pressures or favouritism.

In Poland, the Act of 16 September 1982 grants the Council of Ministers wide-ranging powers over recruitment, promotion and remuneration. The Council determines which positions are to be filled by civil servants and lays down the procedures and regulations governing career development, performance appraisals and salaries. However, in practice, ministries are given a free hand and it can sometimes prove difficult to offset partisan concerns.

In Albania, a central body is responsible for co-ordinating personnel issues: the Department of Public Administration attached to the Prime Minister's Office. However, until the introduction of the 1996 Act, each ministry, and even each service, was free to formulate its own regulations governing recruitment, career development, discipline, etc.

In Hungary, within the framework defined by the law, ministerial department heads are also granted a high degree of autonomy. The distribution of tasks within ministries depends on specific circumstances. For example, several directives of the Ministry of the Interior lay down the conditions under which the head of personnel (Chief of the Department of Matters of Personnel Management and Labour) is responsible for personnel policy within his ministerial competence (he prepares decisions relating to 
disciplinary matters or recruitment). Department heads are given authority over managerial and support staff, and over personnel employed by agencies directly under their control. At the Ministry of Justice, department heads are granted substantial autonomy. The same sort of diversity exists in Poland where, depending on the ministry, decisions are taken by the minister himself or by his directors. The situation is different at the Ministry of Social Affairs, where most important decisions are taken by the Secretary of State, but the directors of individual departments also have fairly significant powers of recommendation.

In Estonia, despite the formal existence of a mechanism for co-ordinating and managing personnel policy, there is no central authority invested with real powers in this area. Ministers remain free to manage personnel placed under their authority as they see fit.

The Estonian case is a particularly striking example of the difficulty of putting in place permanent co-ordinating mechanisms. A commission on the development of the public administration was set up in August 1995. This commission was chaired by the Secretary of State (Head of the State Chancellery). A specialised department was created in the Chancellery to provide permanent co-operation and co-ordination between ministries and public bodies, and to resolve problems concerning the application of the civil service regulations. However, this department was disbanded a few months later, having failed to find qualified staff and especially due to the refusal of ministers to relinquish their powers over the implementation of administrative reforms.

In Poland, the Act of September 1982 assigned a co-ordinating function to the Office of the Council of Ministers. In March 1994, this office began to push for the introduction of personnel management units in each ministry, governed by uniform regulations. The results did not match the great ambitions. Generally, the recommendations of this body in the area of personnel management are not always acted upon by ministries, and the role of the Prime Minister is rather poorly defined. This is not to say that the head of government does not exert any influence on personnel policies, even if it is only because he is the one who initially determines the amount of operating funds likely to be allocated to each ministry, the final amount being established in the Finance Act. But this influence appears more as a means of preserving the overall budgetary equilibrium and of arbitrating between various political options rather than a way to implement public policy.

Hungary has achieved greater success in this area, probably because its ambitions have been more modest and because a more solid institutional support was chosen. Taking the German solution as a model, the Ministry of the Interior has been given extensive responsibilities: it takes part in the formulation and definition of the legislative and regulatory framework, and makes proposals regarding salaries, training, etc. (although the Prime Minister's Office remains responsible for the management of high-level officials for the entire public sector). For these tasks, the Ministry of the Interior relies on a personnel register: this database on the civil service contains the essential elements (age, sex, qualifications, category, knowledge of foreign languages, etc.) required to implement personnel policy. As in Poland, however, this ministry must co-operate with other ministerial departments (Finance, Labour) as well as with the Administrative Reform Commission. It is not certain that the relations between these different bodies are free from tensions, which can lead to dysfunctions.

\section{Recruitment and Selection}

Real recruitment procedures and conditions (shortage of candidates, diversity of selection criteria, etc.) represent one of the major problems in the four countries studied. However, the progress made since the transition began should not be forgotten: abolition of centralised party control; introduction of new selection methods; growing importance attached to formal qualifications. Screening procedures fluctuate 
between the temptation to retreat into formalism and an attraction for more "modern" techniques, such as interviews and tests to determine managerial abilities. As in many Western countries, competitive examinations (concours), selection on the basis of applications or more sophisticated methods are generally disconnected from any analysis of the position to be filled (job description).

The low number of candidates and the resulting lack of competition for positions are often cited. Many explanations are put forward: difficulties in communication and living conditions in certain isolated areas of Albania; on the contrary, competition from the private sector in the capital (Estonia); limited career prospects (Hungary); low salaries which are not commensurate with the level of responsibility. The difficulties encountered in some posts are also blamed: in the sector for the control of enterprises in Albania, the high level of responsibility and the problems linked to corruption, which are difficult to avoid, are cited as reasons for difficulties in recruitment. As a general rule, for certain specialists, such as computer scientists, lawyers and economists, better conditions are offered in the private sector. This has led to the recruitment of candidates who do not have the necessary training or professional experience, and has forced employers to seek emergency solutions, such as the employment of students on a part-time basis (Estonia).

Not only are salaries higher in the private sector, but also the responsibilities and prestige attached to jobs are often greater (but not in all cases, as the case of Albania shows). On the other hand, social benefits are often fewer in the private sector.

Furthermore, selectivity is greater or lesser depending on the post or the sector. In Hungary, such differences reflect the level of salaries and bonuses (see below). In Estonia, new recruits are sometimes offered high salaries in order to attract young graduates with a knowledge of foreign languages. Some salaries reflect the attractiveness of positions offering decision-making powers. Other factors seem to play a role, such as the feeling of "doing something important" (for the transition and for the country) or the possibility of obtaining study grants (see below), in which case the civil service is simply perceived as an extension of the education system.

In most countries, recruitment is left to the discretion of ministers. Compliance with objective criteria such as age, qualifications, etc., as stipulated in the legislative texts, may sometimes prove difficult in practice. Even when provision is made in the regulations for a competitive examination, the lack or low number of candidates may make the procedure inoperable, as in Estonia. Often the selection procedure consists of a short interview aimed at determining whether the candidate possesses the necessary qualifications. Normally, a candidate is recommended by the head of the department in question and then officially recruited by ministerial decision. In these conditions, professional or personal networks constitute the main recruitment source.

It is worth noting the lack of consensus on the optimum method of recruitment and the concern of heads of department to retain control over the choice of their colleagues. The arguments advanced to support this attitude are not without merit. When the number of candidates is such that considerable efforts have to be made to persuade the successful candidates to enter the administration, personal networks can provide useful assistance. Managers also argue that they need to have the support of teams in which they can have confidence, and that it is important to guarantee the cohesiveness of such teams. Nonetheless, several of the conditions for objective recruitment procedures cannot always be guaranteed: publication of job vacancies, procedures ensuring the observance of rules regarding formal qualifications (or other criteria). This could jeopardise the neutrality and appropriateness of the recruitment decisions taken. A certain number of initiatives undertaken to make recruitment procedures more objective deserve to be mentioned, as they may encourage future efforts. 
In Albania, recruitment is included among the discretionary powers of ministers and selection is made on the basis of applications (including an interview for "important" positions). Recruitment is still not really competitive and it would seem that personal recommendations still play a determining role.

In Estonia, the principle of open competitions (obligatory for the highest positions, optional for the rest) laid down by the Civil Service Act proved to be inapplicable: besides the insufficient candidatures, the procedures foreseen were much too slow and complicated. Under the Act, all recruitment decisions must satisfy a number of conditions: degrees, professional qualifications, personal abilities (communication skills, autonomy, ability to handle stress, etc.). These criteria were established for different levels of responsibility, with the particular conditions required for each position being defined by a Competition and Evaluation Committee. The job vacancy notices detailing the qualifications required of candidates must be published. The 1996 Decree foresees a detailed recruitment procedure, with particular reference to the powers of the Committee. In practice, this procedure is rarely followed. The prevailing opinion is that such a system is too complicated and time-consuming to put in practice. More often than not, candidates are unaware of the selection criteria and have no idea as to how to prepare their application. Due to an insufficient number of candidates, recruitment is often carried out on a fairly informal basis using an ad hoc approach (through the mobilisation of personal networks). Despite the complexity of the procedure and the unrealistic nature of certain legal requirements, several ministries have attempted to organise open competitions to fill the highest positions, by introducing criteria to identify managerial abilities. Generally speaking, however, responsible officials are critical of the strict criteria imposed on the Competition and Evaluation Committee and prefer to choose themselves the most suitable person to integrate into their team.

Another lesson can be learned from the Estonian experience. Pursuant to Decree No. 124 of 2 May 1996, each job must be defined, specifying the "main duties and responsibilities, managerial rights and powers, and the criteria for success in achieving objectives", etc. As the Estonian report points out, such job descriptions are less focused on the objectives to be achieved than on the protection of established officials in relation to their supervisors: for example, on how to convince supervisors of the need for additional resources in personnel or equipment, or how to show that the projects allotted to them are impossible to achieve, etc.

In Hungary, the law imposes neither the advertisement of job vacancies nor the use of competitive examinations, and the selection process is usually carried out through interviews (which are sometimes supplemented with psychological tests). This lack of formalism leaves a wide margin to the personal impression of the head of the department, without whose agreement the candidate cannot be recruited. When posts to be filled attract a greater number of candidates (e.g. the Patents Office), then a bona fide professional examination is organised. The recruitment criteria consist of a mix of professional qualifications and personal qualities.

In Poland, the law and regulations define the conditions for recruitment. Job vacancies are rarely advertised, but vacancy notices may be issued for highly specific positions. Some commentators wonder whether such advertising is not simply a waste of money. In theory, the selection procedure is the responsibility of the personnel department and recruitment is sometimes carried out by choosing between reserve candidates whose applications are stored in a database. In theory, this department is responsible for verifying that all the objective recruitment conditions for a particular job are fulfilled (age, degrees, abilities, etc.). However, in practice, the personnel department must often limit its involvement to purely formal aspects of the procedure, namely the verification that the documents and attachments required under the regulations have been provided. Consequently, compliance with regulatory requirements (level of degree, application of pay scales) may lead to conflicts with the head of department concerned. Changes made in most personnel departments in 1989, however, have encouraged the latter to adopt a 
more conciliatory attitude towards possible political pressure. However, the situation varies widely from one sector to another. The Ministry of Education (which is relatively unpoliticised) is attempting to formulate its own personnel policy and plans to reduce the average age of its employees (and the proportion of women) by the year 2000. In the Ministry of Culture, politics play a role especially among the lower and middle grades, whereas professional qualifications are paramount at the upper levels.

Moreover, an interesting reform aimed at setting up system of job descriptions was attempted in Poland in 1993. The personnel and training unit attached to the Office of the Council of Ministers tried to introduce job descriptions in the framework of establishing uniform recruitment and selection principles. This unit was made responsible for formulating a method to analyse and describe the required jobs and profiles, together with a selection method permitting the identification of the necessary skills in candidates. The project was carried out with the help of a private consultant and specific training was organised. The Office of the Council of Ministers and the Ministry of Commerce and Industry were even equipped with tailor-made software (the Thomas Personal Profiling System). However, this system was never really used. None of the selection principles developed during the training seminar were ever applied. It is worth noting that recruitment was occasionally preceded by an interview. No systematic approach to job descriptions was adopted in other ministries. Nevertheless, it is widely accepted in Poland that the lack of definition of job profiles means that the introduction of a policy for human resources management in the administration would serve no useful purpose.

In all four countries, appointments are made after a trial period which varies in length (the period is sometimes prescribed by law). In Estonia, fixed-term appointments are foreseen for specific tasks: drafting legislation, formulating programmes, and projects requiring specialised expertise. In Hungary, fixed-term appointments are used in the place of trial periods: officers are appointed as if they were to accomplish a specific task, and at the end of the set period a final recruitment decision is taken on the basis of their past performance. 


\section{TRAINING}

The problems facing the training systems in the four countries studied are intrinsically no different than those encountered in some Western countries: lack of a clearly defined training policy at national level, absence of formulated objectives, lack of co-ordination between ministries, uneven distribution of resources and access to training, insufficient evaluation of needs in relation to available resources, absence of any assessment of the content and impact of training seminars, difficulties in motivating personnel, etc.

Nevertheless, in several countries a tradition exists in this area, sometimes inherited from the communist era or even earlier, and training is valued highly. Hungary in particular has had a lengthy practical experience in training, including in the administrative field. State officials have long been familiar with the managerial approach and the College of Public Administration was established in 1977. In Estonia, however, the inadequacies of arrangements for training are considered to be one of the main weaknesses in the system. On the one hand, the reduced size of administrative structures and the limited number of concerned officials, and on the other, the high turnover of personnel are obstacles to the implementation of adapted professional training courses.

On the whole, however, it would seem that the former training institutions inherited from communism are not sufficiently equipped to cope with current requirements. Training would be the first sector to benefit from the development of mechanisms to formulate and implement a co-ordinated human resources policy.

Training prior to employment is provided in various ways. Universities are responsible for general education in the fields of law, economics and sometimes even public administration. In Estonia, there are six state and several private universities, and a degree in public administration has recently been introduced. In Hungary, the High School of Public Administration (funded by the Ministry of the Interior), several universities (the Budapest University of Economics, law faculties of Szeged, Mitolk, Pécs), and a growing number of private schools offer training in public or private management. These institutions operate independently of one another, and have developed a fair number of links with international programmes (either bilateral or multilateral). To a certain extent these institutions compete with one another for a dominant position in the training market. In Poland, the only institution which prepares for entry into the administration is the National School of Public Administration (KSAP), set up in 1990. Based on the French model of the ENA ${ }^{4}$, the KSAP offers a two-year postgraduate course designed to prepare civil servants capable of filling management and planning positions in the top administration. The initial ambition was to provide both neutral and high-quality training with a view to establishing a civil service system based on merit. Admissions selection to the School and a solid training in law and management were intended to prepare a new generation of civil servants instilled with the values of neutrality, efficiency, and respect for the rule of law. In practice, it would seem that although graduates of the National School of Public Administration are appreciated for their good theoretical knowledge, according to personnel directors their training is too remote from concerns in the field and their lack of

3. For further information on training systems, see SIGMA Papers: No. 16 - Public Service Training Systems in OECD Countries, August 1997.

4. Ecole nationale d'administration, National School of Administration. 
administrative know-how makes them ill-suited to fill important positions in the administrative hierarchy. In 1993, a Decree issued by the prime minister set up the In-service Training Council, placed under the responsibility of the director of the National School, in order to remedy this situation. The problem, which is not limited to Poland, is one of a training system whose organisation is excessively based on supply and insufficiently on demand.

In-service training is an important issue in central and eastern European countries. The ambition to create a new civil service calls for a major effort to change the practices, abilities and administrative culture of career officials working within a highly rigid and hierarchical command structure ${ }^{5}$. The scope of these requirements is extensive and ranges from mastering techniques to learning new values, as well as certain aspects of management and various branches of the law. Another issue for training is Europe. Three of the four countries studied have clearly expressed their ambition to join the European Union, and to consequently modify their structures, law and policies. Openness to the outside world, to other European languages, and knowledge of Community law and practices are considered as priorities.

Given these ambitious goals, in-service training, despite significant improvement, appears to be insufficiently developed. This raises several problems, such as the links between training and career development, and the possibility for the administration to benefit from investments in training (in other words, to prevent newly trained officials from seeking to capitalise on their skills in the private sector).

In Estonia, continuing education in the administrative field falls within the responsibility of the personnel department of the State Chancellery. Until now, this department has focused its attention primarily on the Estonian Institute of Public Administration (EIPA), and generally ignored the other existing training courses. The EIPA, like many of its counterparts in other countries, does not really make enough of an effort to advertise its courses nor to keep abreast of the administration's needs. It is even more difficult to convince potential applicants as its programme does not appear to be sufficiently attractive or substantial.

The same difficulties characterise the Albanian Institute of Management and Public Administration (IMPA), which offers courses that do not relate closely enough to concerns in the field. The relations of the Institute with the ministries is diversely appreciated: according to the ministries, the Institute's courses are poorly adapted, as to they do not respond to the ministries' needs.

In Poland, the In-service Training Council which was set up in 1993 has produced a comprehensive report, in collaboration with OECD/SIGMA, on "the basic elements of in-service training for civil servants", which constitutes a valuable reference for defining in-service training.

In Hungary, a three-tier training system has been introduced:

- The general examination in public administration (Government Ordinance No. 51 - 1993) is part of a programme aimed at updating the professional knowledge of officials already in place prior to transition. The examination contents includes basic subjects such as institutions, general principles of functioning of the administration, administrative procedure, principles of public finance, management and data protection. This examination system reflects the willingness to reinforce the unity of the public sector: it is obligatory for all

5. See Barbara Numberg, The State after Communism: Administrative Transitions in Central and Eastern Europe, EMTPM Regional Initiative on Public Administration in Central and Eastern Europe, November 1995. The scope of requirements is extensive and ranges from technological know-how to the acquisition of new values, management and certain aspects of law. 
public service officials (with a few exceptions defined by the Act and Ordinance No. 46 of 24 April 1995). Those who fail must leave the administration.

- The professional public administration examination must be taken by all public service officials (also with some exceptions) at a given moment in their career. This is a more practical examination than the general examination mentioned above, and covers a number of management principles and certain elements relating to the law of the European Union. The aim of this examination is to confirm the professional competence of public service officials and to prepare them for carrying out general tasks in the administrative area. Those who fail remain in the lower grades (e.g. employee II, junior clerk II, administrator II or referee II), which denies them access to numerous financial benefits, in particular the bonuses awarded to higher categories.

- Finally, high-level seminars are organised with the co-operation of international organisations and foundations. The Phare Programme of the European Union is one of the most important of these training partnerships. A fairly large number of public officials attend these seminars, which allow them to expand their professional horizons internationally.

The Hungarian system is one of the most ambitious to have been introduced in Central and Eastern Europe, although opinions are divided, even in Hungary itself, regarding the quality of the training provided and the level of examinations. Some consider that the professional level required remains low, and that the examinations focus more on the assessment of formal knowledge than on professional know-how. Those responsible for the examinations point out, however, that once the principle of holding such examinations has been accepted, they could gradually be made more selective. Hungary is the only country to have attempted to bring its civil service up to global standard and to have laid the foundations for training to play a role in career development. However, the new system is criticised for not being more voluntary in nature. Critics also point to the fact that professional training programmes sponsored by private enterprises play a significant role in the training "market". As these programmes are often too expensive for the administration, they regrettably lead to differentiation between employees in the public and private sectors. 


\section{CAREERS}

Three of the four countries have clearly opted for a career-based system, which does not rule out the possibility of dismissal in case of reorganisation or, in certain circumstances, professional incompetence. In Estonia, a job-based system was chosen, which means that an appointment is linked to the occupation of a specific post . Nevertheless, this does not appear to have led to any significant differences (nor that one system should be preferred over the other, the main issue being how the system should be implemented).

In Hungary, dismissal on the grounds of reorganisation has become rather rare. A widespread practice, when there is a change of minister, is to offer certain senior civil servants a more or less equivalent new post in order to avoid the costs of dismissal. Dismissal is foreseen in the event of failure in the general administrative examination. However, it is also possible in the case of the abolition of administrative bodies or if posts have become superfluous to requirements. Dismissal can also be the consequence of professional incompetence or disciplinary action. A civil servant can still be dismissed if he has received two unfavourable evaluations, but this is extremely rare in practice. In spring 1995, the government decided on a 15 per cent reduction in the number of public officials. In practice, individual administrations complied with the reduction requirement by eliminating precarious positions, occupied by either part-time or retiring staff, without any consideration of the real utility of the positions which this saved.

Furthermore, it should be noted that competition from the private sector is not only a source of the recruitment difficulties discussed above but also a cause of departures. The importance of this phenomenon is difficult to evaluate and the figures, when they do exist, are incomplete. In Hungary, however, the introduction of the Civil Service Law has played a key role in stabilising the civil service.

Career prospects outside the administration have sometimes been overestimated, leading to some disillusionment (e.g. Estonia). Generally speaking, it is primarily young recruits with the highest qualifications who choose to leave. The most attractive sectors are finance and banking, state enterprises, privatised companies (in Estonia, civil servants who have participated in privatisations, on the national or local level, are often found at the head of the enterprises in question).

\section{Performance Appraisal and Promotion}

In all civil service systems, career development is based on two factors taken into account simultaneously: seniority on the one hand and assessment of professional skills on the other. While the first of these elements poses no particular problems, given that advancement is automatic, the second is much more delicate. And yet it is on the latter which depend the motivation and professionalism of civil servants. However, as in many Western European countries, setting objective criteria for performance appraisals poses many different kinds of problems, despite the provisions in legislative texts which, in some cases, lay down precise procedures.

The difficulties involved in assessing and rating civil servants and public officials are more or less the same in most civil services, both inside and outside Europe. The progress that can be made in this area is 
therefore very relative. There is no miracle cure and even in the best systems most officials end up by receiving good marks, so that in the final analysis the main criterion for promotion is seniority.

In Poland, for example, the legislation provides for performance appraisals of officials every two years. The new law provides for the creation of standardised technical dossiers and evaluation sheets. However, due to the lack of regulations setting out precise criteria and indicating the subsequent action to be taken, the very principle of appraisal is resisted. In the eyes of employees, appraisals are a possible weapon which can be used to justify dismissals; in the eyes of the hierarchy, appraisals can be a pretext for asking for salary increases. There are some who challenge even the idea of communicating to employees the results of appraisals which concern them. In practice, since concrete procedures for rating have yet to be defined, administrations are free to decide whether or not to conduct appraisals.

In addition, even though the experience and abilities of the officials are taken into account, other more subjective factors, such as personal or political links to their hierarchical superior, can play a role, particularly in view of the fact that promotions are awarded at the minister's discretion. The minister himself reviews the performance and professional qualifications of the official, possibly after consultation with directors. The weaknesses of the system have repercussions on both the training system (absence of needs assessment) and promotions, for which criteria are lacking. In some ministries, promotions, which are the only means of increasing salaries, are decided on a case-by-case basis according to the importance attached to professional qualifications, and their scarcity on the market, and through networks of personal relations. Other ministries have made major efforts to establish regulations in this area, in particular the Ministry of Agriculture and Ministry of Education. The latter is noteworthy for its firm resolve to develop and implement an effective personnel policy.

In Estonia, there are no formal criteria for promotions, except for the basic requirement of a minimum of six months in the previous position. Nonetheless, superiors must justify their promotion proposals to the relevant minister or director. Decree No. 124 of 5 February 1996 governing career advancement mentions both personal qualities and objective criteria. The appraisal system attempts to place in parallel the formal job description, the specific requirements of the post and the assessment of the official's personal qualities made by the official's supervisor. There is therefore a certain degree of subjectivity involved. The system of promotion and advancement is currently being revised in Estonia.

Hungary is the only country to have established a sophisticated system for individual assessment. Public officials are evaluated at least once before being promoted to a higher grade. The goal of this evaluation is obviously to pass an objective judgement on the professional performance and personal qualities of the official and to determine whether he/she deserves to be assigned to a higher position. The department head must justify his assessment, as it will have important consequences for the professional future of the person involved. At the same time, the candidate must be informed of the results of the performance review and countersign the assessment sheet completed by his superior. The candidate may add his own comments, appeal to the labour tribunal or even challenge the decision which has been made concerning him. However, as in many Western countries including France, one of the perverse effects of this fairly elaborate system is that hierarchical superiors tend to avoid conflicts by making more or less positive assessments of their staff. This situation is not confined to Central and Eastern Europe, but in these countries the attitude of evaluators seems also to be motivated by negative memories of the past.

In Albania, a decree of the Council of Ministers on the files of civil servants of 29 January 1996 sets out the criteria for performance appraisal. It has been partially implemented, but it is envisaged to develop evaluation by linking it to remuneration and career development. 


\section{Mobility}

Horizontal mobility, i.e. between departments within the same ministry but particularly between ministries or between ministries and subsidiary agencies, is another component of career development. It complements vertical mobility resulting from advancement or promotion.

In Western European countries, mobility varies widely from one country to another and also according to the degree of co-ordination of personnel management policies. Although it is difficult, as a general rule, to appraise horizontal mobility, in the four countries studied it would seem to be often weak or non-existent, which might be attributable, inter alia, to the high degree of autonomy granted to each ministry in the management of its personnel.

Hungary is an exception in this respect, although mobility is promoted by dismissals occurring on the grounds of economic rationalisation. Otherwise, vertical mobility is ensured through promotion to higher positions. Until June 1990, transfers were only possible within administrative services as such. Since then, they have been extended to all public service bodies in the broad sense of the term: administrative agencies, independent bodies funded by the budget, courts, the armed forces, etc. However, the fragmentation of personnel management obviously makes it more difficult to implement genuine employment policies.

In Poland, it is hard to incorporate mobility in a system in which officials are primarily considered to be employed by a specific ministry (and not by the state). Mobility gives the impression of a disciplinary measure, as are decisions to place officials at the disposal of the human resources department. The legislation provides for the right of contractual officials to refuse a transfer, but not civil servants. 


\section{REMUNERATION}

All remuneration systems attempt to reconcile two imperatives: maintaining overall budgetary equilibrium and motivating officials. In a general framework established by law, the room for manoeuvre enjoyed by managers varies.

In Hungary, the 1992 Act lays down the main components of remuneration: basic salary, bonuses, thirteenth month ${ }^{6}$. Government Ordinance No. 170 of 22 December 1992 details the various types of bonuses which can be awarded. The basic salary is calculated according to a minimum rate set by Parliament (currently FT 23 400). Each official's salary is fixed according to his position in the hierarchy (class, grade, step) by applying a multiplying coefficient. Within this common framework, ministries have substantial freedom to determine the size of salaries and bonuses. The law authorises variations of up to 20 per cent for officials falling in the same pay category, on the condition that the wages paid are covered by the employing body's own funds, a privilege enjoyed only by selected bodies (e.g. the Patents Office). Local authorities apply the same system but have more room for manoeuvre: the basic salary can be set at a different level by a decision of the local assembly and even the coefficients can be modified. As a result, major differences can exist between different employees and from one body to another. Certain officials are also awarded bonuses or supplementary allowances, while others are not. The salary envelope for each ministry or administrative body is allocated by the Treasury on the basis of the posts provided for in the budget. Consequently, administrations are able to use salaries corresponding to vacant posts in order to redistribute them in the form of bonuses or other allowances.

In Poland, salaries are regulated by the 1982 Act and the Decree issued by the Council of Ministers in April 1995 relating to state officials. However, salaries are commonly-based only in the way in which they are calculated. As part of the annual budget exercise, the budget directorate of the Ministry of Finance establishes, with the approval of the Council of Ministers, the total wage bill for the public administration. It should be noted that, as in most Western countries, Poland has renounced the indexation of salaries to increases in the cost of living, which had constituted an inflationary factor. Salary increases are decided through negotiation between the ministries concerned (Finance and Labour) and the main unions. It is mainly the Ministry of Finance which determines the annual wage bill to be allocated to the different ministries. The Ministry of Labour collaborates in this allocation process, but its role in fact extends even further, undoubtedly through a reversion to former practices where the ministry had complete authority to determine salaries for all workers. In fact, ministries, public bodies and union organisations refer to the Ministry of Labour for implementation, or even adjustment, of the salary scale. Apart from this, the process of fixing salaries, and more generally the management of personnel remunerated under the public budget, is highly decentralised. Each ministry is fairly free to set the amount of remuneration applicable to its staff (with the exception of the tax authorities, customs officials, and ministers themselves, for whom specific rules have been laid down). This freedom is manifested by the possibility to draw from the wage bill the sums corresponding to unfilled posts in order to raise the remuneration of established officials. This results in a high (unspecified) proportion of vacant posts.

6. End of the year bonus equivalent to one month's pay. 
In Estonia as well, ministries keep posts in reserve in order to increase salaries or to meet unforeseen needs. Similarly, the creation of new structures is often motivated by the creation of new managerial posts.

Nevertheless, it might be asked whether these posts are superfluous to requirements or whether the fact that they remain vacant means that the administration is understaffed. The limited development of personnel management tools makes it difficult to answer this question. An alternative solution might be to carry out a proper analysis of the tasks to be undertaken, accompanied if necessary by an increase in some salaries.

In Poland, each public authority has a personnel department which keeps up-to-date individual records of staff members (including all the information concerning their identity, family situation, degrees, career, etc.). This department is responsible for examining the compatibility of the minister's proposals for individual promotions with the rules in force and with the files of the persons concerned. As we have already seen in relation to recruitment, in practice the personnel department gives its approval in almost all cases. Files are managed manually as there is no integrated interministerial information system, whether it be manual or computerised. Salaries are paid in cash. According to the regulations, a pay scale called a "salary bracket" is linked to each category of posts. The level of each bracket is set annually by the Ministry of Labour and Social Affairs in consultation with the Ministry of Finance.

In all the countries studied, salaries differ significantly depending on the job and on the administration. For example, in Poland the officials of the Supreme Court earn on average nearly three times more than those of the ministry where salaries are the lowest, which is the Ministry of Justice. The average salary at the Ministry of Finance is twice that at the Ministry of Justice. Similarly, the salaries of officials working for local authorities are generally higher than those of officials working in the central administration. Salary amounts are set by the local authorities themselves. In Poland, these authorities manage to boost the remuneration of their personnel by giving them minor additional duties (instead of resorting to external personnel). This is similar to Estonia, where certain authorities, such as customs, tax and the privatisation agency, are authorised to pay salaries 20 per cent to 40 per cent higher than those contained in the pay scale.

Another important issue is the difference in salaries between the top and bottom of the hierarchy. If total salary (including bonuses and allowances) is taken as the reference, the gap is very narrow in Albania (1:2). In Poland, the gap is wider, between 1:4 and 1:4.5 on average, although there are significant variations from one administration to another. In Estonia, limiting the comparison to the difference between pay scales produces a much wider gap (officially 1:7), but in reality the gap is smaller as salaries rarely reach the highest steps. Nonetheless, of the four countries studied, Estonia has by far the most differentiated hierarchy. Hungary comes fairly close to the current averages of Western European countries, with maximum ratios of 1:7.5 for the civil service understood in the strict sense, and 1:5 for public service officials. However, in this country the minimum salary established by the 1992 legislation should be taken into account, which narrows slightly the scale of public service remuneration.

One of the major problems faced by the four countries studied, as with most countries in transition, is the rapid expansion of the private sector which offers higher salaries. The remuneration in the administration is not always attractive enough to young and highly qualified top officials, particularly in Poland and Hungary. How is it possible to maintain a remuneration and career system which will keep the most able and best qualified staff from leaving the administration? Apart from general but necessarily limited measures, such as a global increase in salaries (which is largely dependent on budgetary constraints) specific incentives are used. For example, top officials are offered the possibility to represent the state on the board of directors of nationalised companies. For example, in Hungary this system has in some cases 
allowed officials to double their salaries. Plurality of offices with another public, or even private, activity is often tolerated (either by law or in practice). These activities are subject to varying degrees of regulation (see below). In Albania, the remuneration received in the framework of authorised secondary activities cannot exceed two months' official salary annually. However, the regulations are sometimes circumvented. In Estonia, it happens that civil servants are also active as consultants in private firms.

The best incentive remains bonuses, which can be awarded to employees as recognition of their special qualifications or as a reward for exceptional performance. Two types of bonuses are generally used. Those linked to objective criteria (family allowances, relocation allowances, foreign language bonuses, bonuses for activities posing a risk to health or safety, etc.) are awarded automatically. As in other countries, bonuses relating to the exercise of a particular function or to performance may be used for other purposes and awarded indiscriminately as a means of raising the salaries of all or some of the personnel, subject to the availability of funds. In Poland, depending on the administration concerned, the proportion of salaries paid in the form of bonuses varies between 4 per cent and 60 per cent.

Such bonus payments can sometimes lead to major disparities in remuneration allocations. As a general rule, wage disparities are not confined to the countries studied and the privileged position that the ministry of finance enjoys in many countries allows it to offer its officials more advantageous careers or bonuses. The lack of transparency in the distribution of bonuses can also be observed in Western countries, as well as other well-known practices such as reserving special treatment for control administrations (as well as the ministry of finance) or giving preference to undifferentiated bonus systems based on the hierarchical position rather than on the performance of the persons concerned. Nevertheless, these disparities would still seem to be exacerbated by the autonomy granted to ministries and local authorities, and the natural play of the labour market which tends to offer higher remuneration for the most sought-after positions. These differences also have the effect of discouraging the most able candidates from entering sectors lacking in funds and offering lower pay. Further, they encourage a growing imbalance between politically influential ministries and others which are less so.

The overall impression given by the four countries studied is one of wide diversity in remuneration depending on the ministry, on whether the official belongs to the central or local public authorities, and even on the location. It is true that public service pay policy cannot simply ignore the realities of the labour market and the premium placed on certain professions. 


\section{RIGHTS AND DUTIES — PROFESSIONAL ETHICS}

Formerly, rights and duties in the public sector were governed by the labour code. Its provisions were generally rather vague, while violations were not always punished nor rights always defended. Rights and duties are now defined by the civil service law. However, on several crucial issues such as conflict of interests and incompatibilities or the duty to inform the public (and confidentiality), the legislative texts often remain vague. In the absence of any precise criteria defining, for example, the boundary beyond which the public interest might is in jeopardy by the exercise of a function in the private sector, and in the absence of any workable procedures, the legislation seems to go no further than the formulation of some general principles. In contrast, when the regulations are too detailed, as in Estonia, they cannot be readily enforced.

In general, the main duties of civil servants are:

- respect of the Constitution and the law;

- obedience to superiors (subject to certain narrowly defined restrictions);

- impartiality, honesty;

- objectivity;

- keeping the public informed;

- "devotion" (Albania);

- preserving the image of the public service and state secrets (Hungary);

- attendance at training courses and examinations (Hungary).

The rights are defined in different ways: job security (Albania, Hungary), the right to receive training and a salary, the right to not be transferred against one's will, the right to join a union. Hungarian law also recognises rights of a political nature. The right to strike exists in Hungary (but its limits are set in accordance with an agreement signed by the government and the unions in 1994) and in Poland, but not in Albania; Estonian legislation, which had initially denied the right to strike, was amended in this regard in December 1995.

The existence of unions is more or less recent depending on the country. On the whole, relatively little information is available on the rate of unionisation in the civil services of the countries studied, but it would appear to be low, and the unions sometimes suffer from the negative image inherited from the Soviet period. In general, collective bargaining has not yet been introduced (nor has union participation in management); Hungary, however, is an exception in this respect.

The Hungarian Civil Service Law makes detailed provisions in this area and the unions play a significant role. The legislation recognises their role in representing employee interests and grants a right of access to information allowing unions to intervene in disciplinary proceedings at the request of the official concerned. Unions are authorised to participate in the Forum for the Reconciliation of Civil Service 
Interests, a consultative body set up in 1993, and also in collective bargaining. This forum appears to have played a positive role in the formulation of ethical standards (see above) and in the area of salaries.

Significantly, the sensitive issue of the plurality of offices is dealt with, depending on the case, either under the heading of duties or under that of rights.

In Albania, the law grants a civil servant the right to exercise a secondary public activity "if this activity does not conflict with his [primary] functions" (an older ordinance of the Ministry of Finance had already prohibited customs and tax officers from working in the private sector).

In Estonia, an authorisation of plurality with a private activity may be granted by the hierarchical authority provided that the activity does not either encroach upon the exercise of functions or damage the organisation's reputation. Membership in the managing or supervisory bodies of commercial companies is forbidden. However, this restriction does not apply to public enterprises. In practice, a number of senior civil servants combine their positions with consultancies or other activities. The law requires that all civil servants submit annually a detailed declaration of their real and personal property, including the number of cars, boats, planes, etc. In any event, no provision has been made for sanctions and the public authorities lose some of their credibility by formulating, at regular intervals, detailed regulations governing gifts to civil servants.

Regulations have been introduced in Estonia to prohibit departures of civil servants to companies over which they have had supervisory power. However, it is not known whether these provisions of the Civil Service Act are enforced, simply because there is no centralised register providing information on positions which include such control functions or on positions occupied by civil servants who have left the administration. It may be noted in this respect that the availability of personnel management tools is a precondition to enforcing compliance with the regulations. In addition, this problem is connected to the issue of incompatibilities. On this point, the Estonian report notes that it is becoming more beneficial in some cases to hold simultaneous positions in the public and private sectors rather than to leave the civil service for a private career, which sometimes proves disappointing.

The Hungarian law tackles the issue of incompatibilities. It forbids civil servants to hold an elected office if this falls within the scope of their professional responsibility. The exercise of private activities is subject to authorisation and must not risk compromising the neutrality and impartiality of the official concerned. Senior civil servants are prohibited from holding any other position (with the exception of certain intellectual and artistic activities such as teaching). Membership in the managing body of a private enterprise does not fall within the scope of incompatibilities, provided that this membership does not represent a conflict of interests, in which case the law requires that the official resign (which is automatic or with a notice period of 30 days).

In Poland, the law is very strict concerning incompatibilities. Plurality of offices is forbidden without the authorisation of the department head. Permission may not be granted if there is any suspicion that the impartiality of the official concerned might be compromised or that there is a risk of a conflict of interests. Procedures are more flexible in practice, however, but differ from ministry to ministry. Permission to exercise another activity is rarely granted by the Ministry of Labour and Social Affairs (except for teaching activities which do not encroach upon administrative working hours). In contrast, at the Ministry of Commerce and Industry, as at the Ministry of Culture and the Arts, authorisations to occupy a secondary job on a part-time basis can be readily obtained. The reason for this is that they constitute an incentive for officials to remain in the public sector. In some cases, a narrow interpretation of the concept of additional work, as provided in the Labour Code, allows officials to dispense with an authorisation altogether. The law also prohibits the membership of civil servants in the managing and supervisory 
bodies of private companies, with the exception of persons appointed by law to represent public interests. In the latter case, a debate has opened up on the legality of remunerating such officials; the Ministry of Justice has revealed the names of those officials who have received such indemnities, and threatened them with legal action. However, these threats have not been followed up, although some of the civil servants in question have been replaced and it now seems that such functions can no longer be remunerated.

Individual behaviour cannot be readily appraised and reflects prevailing values. Progress has been made in this area, although the indifference with regard to the public that was common during the communist era has often been perpetuated. The Albanian report lists some of the characteristics of the civil service: arrogance, servility, slowness. According to the Estonian report, a bureaucratic attitude and individualist culture are the main threats to the public interest. In Estonia, frequent changes of ministers have led to unstable working conditions. The result is lack of motivation and indifference to results. Often the interaction between the public service and personal relations constitutes one of the elements defining the civil service culture.

Efforts have been made to draw up codes of conduct. In Hungary, such a code has been drawn up as a result of collaboration between the Public Administration Council and the public service. A debate is being conducted on the question of whether the adoption of standards should be carried out through a consensual process rather than by means of legislation. There is nonetheless a risk that regulations might focus more on protecting the organisation and its image than on ensuring the quality of service provided to users, as the case of the Ministry of Culture in Estonia has shown.

In Albania, a decree of the Council of Ministers of 16 September 1996 governs public service ethics. It contains provisions regarding honesty, impartiality, conflict of interest and also relations with the public.

Poland has not yet succeeded in replacing the former code of conduct dating from the communist era with a new text.

Corruption, which is difficult to assess, is generally considered as a serious problem. The Estonian report analyses, as some of the causes of corruption, the small size of a country where everyone knows each other, the absence of any well-established elite, and the sudden redistribution of wealth which occurred after the transition (as one sociologist remarked, "once everybody used to be poor"). It is widely believed that personal networks play a primary role in the awarding of contracts, and some politicians and senior civil servants even own banks. However, it is a fact that corruption cases are rarely made public or punished. When they are, it is often for political reasons. Obviously, this situation is severely damaging to the administration and its image.

In Hungary, public opinion is very sensitive to problems of corruption, and several events have led to the dismissal of the incriminated officials.

\section{Discipline}

Formerly governed by the labour code, the disciplinary systems in these countries now have a framework of new rules. The complexity of regulations governing disciplinary procedure varies from country to country. Respect of the rights to a defence and to challenge sanctions before an independent body are the key elements which guarantee the objectivity of a system now slowly being set in place.

The disciplinary procedure set up in Hungary involves two phases: an investigation phase, followed by a judgement phase. The rights of the defence are guaranteed (the right to a hearing, to legal assistance or 
representation etc.). In Poland, the disciplinary procedure is a two-tier system within the administration, which is linked to the right of appeal before the courts. Depending on the country, sanctions can be challenged before the labour courts (Hungary), or before the administrative courts (Estonia, Poland). In Albania, the system for sanctions is highly centralised, with the ministry making the decision following recommendations from its department heads. The appeals system laid down by the legislation has yet to be put in place.

However, the implementation of legal pursuits runs up against a number of obstacles such as the fear of scandals which, in some cases, leads to settlements out of court, or even to forced resignations (Estonia, Hungary). Dismissals resulting from disciplinary action are rare. Nevertheless, in Albania approximately 350 customs officials and financial controllers were dismissed over the past year for corruption. In Poland, in the course of this survey only a handful of cases of minor offences (unexplained absences, files not examined before the deadline, etc.) were taken up. In one case of unauthorised pluralism, the official in question preferred to resign; in another, the disciplinary procedure seems to have been abandoned. 


\section{RELATIONS WITH THE PUBLIC}

Civil servants are often the target of public criticism of the slowness and inefficiency of the bureaucracy, corruption, etc. Even though they may sometimes serve as scapegoats for the dissatisfaction of a population used to a paternalistic state, it is also true that civil service culture is not always user-oriented. Courtesy and service to the public are unevenly distributed. In Hungary, when a citizen's complaint regarding the behaviour of a civil servant is found to be justified, the hierarchical authority is obliged to initiate disciplinary proceedings (however, it may be assumed that only serious examples of misconduct would lead to a sanction being imposed).

Even though legislative texts on free access to information exist, they do establish any right of access to administrative information. The duty to inform the public is often couched in weaker terms than the prohibition on revealing secrets or information which might cause prejudice to the administration. In practice, attitudes towards confidentiality vary substantially.

In Estonia, Article 44 of the Constitution imposes a duty to inform the public. This concerns information of a general nature concerning public health, the environment, human rights violations, education, corruption or criminal statistics. The same is true for information on the salaries of members of government and local authorities (but not administrative bodies ...). Nevertheless, the fact remains that in the absence of any specific legislation on freedom of information, public authorities possess a wide discretionary power to determine which information may be divulged.

In Hungary, the publicity of personal data and information of general interest to the public is guaranteed under a 1992 law; however, the conditions governing its implementation are set out in the internal regulations of each body. These regulations appear to give fairly narrow definitions of both the group of persons who benefit from access to the information and the extent of this information. Information regarded as secret is defined in legislation enacted in 1995. Failure to take adequate security precautions and the release of information which could prejudice administrative activities are both considered as disciplinary misconduct.

In Albania, freedom of access to information is governed by different rules depending on the ministry (for example, the Ministry of Finance does not authorise access to documents concerning the budget). Legislation on secrecy is foreseen. 


\section{PUBLIC ADMINISTRATION AND POLITICS}

The way in which each of the countries considered in this survey deals with the issue of the relations between the administration and politics (as mentioned in the introduction to this report) reveals widely differing concepts of the principle of neutrality of the administration and its subordination to government authorities.

In Western Europe some countries, such as the United Kingdom, consider that the administration must remain completely neutral and accordingly maintain a strict separation between political and administrative levels. In other countries, the normal workings of democracy and political pluralism are considered compatible with a certain degree of politicisation, which is associated with the principles of merit and career development. The same diversity is found in Central and Eastern Europe.

In concrete terms, there are several aspects to the issue of relations between the administration and politics. The first is the possibility of combining employment in the civil service with political activities (membership of a political party, militancy, holding of an elected office); the second is the influence of political factors on recruitment and career development. The restriction of politicisation to the higher grades in the civil service is a controversial issue and many consider that some degree of politicisation is acceptable in a period of transition.

Whatever the case may be, it is difficult to assess the situation, since the influence of political factors within a given country can vary substantially from one sector to another and over time. In addition, as noted earlier, political considerations may have less of an impact on higher levels in cases where there is a call for professional skills which are in particularly strong demand on the labour market.

In general there are few limitations on the participation of civil servants in political activities. In Hungary, holding elected offices simultaneously with a post in the administration is prohibited where there is a risk of interference with the responsibilities of the official in question. In Estonia, membership in the governing bodies of political parties is forbidden. In Albania, article 33.6 of the civil service law grants civil servants the right to pursue political activities unless there are contrary legal provisions and if these activities are not incompatible with the exercise of their functions. They are not authorised to occupy positions in political parties or in a political organisation.

In all events, these regulations have little influence over the degree of politicisation of the administration and of senior civil servants in particular. The Albanian law defines a category of "political appointees" who can be dismissed for political reasons. This country, which has undergone the most dramatic changes of the four countries reviewed, experienced a high number of dismissals of this type at the beginning of the transition period. However, the political pressure exerted on the administration is difficult to assess.

In Poland as well, political considerations play a part in recruitment and career development, occasionally at the expense of professional skills and the rule of law. Nonetheless, some ministries, in particular the Ministry of Education, are endeavouring, with some success, to move away from such practices. 
In Estonia, the system underwent the traumatism of the 1990 reorganisations, which led to rapid departures and promotions as well as to over-inflated qualifications. At the same time, for some young officials the administration (thanks to the training and contacts it provides) became a launching pad for careers in the private sector and in politics. This was obviously a source of frustration for those who saw their own career prospects curtailed as a result, especially for older officials who had no alternative but to defend their acquired positions. 


\section{ISSUES FOR CONSIDERATION}

A professional and efficient public administration implies competent, motivated and impartial civil servants working in a system completely dedicated to serving the public interest. While it is relatively easy to draw the profile of a merit-based civil service in conceptual terms, it is obviously much more difficult to define the ways and means of putting such a civil service in place. The specific context of each country, notably the historical, cultural, economic or social factors, often play a far greater role in determining the success or failure of a reform than institutional measures. The opportunities for change may also be limited by political obstacles or budgetary constraints. This does not change the fact that transition is an evolutionary process. Improvements can still be made and there are strong incentives for reform, including the prospect of moving closer to the European Union and the single market.

One of the prerequisites for reform is to make careers in the administration more attractive, not only in terms of salaries and bonuses (which will necessarily be limited by budgetary constraints), but also in terms of guaranteed career development, prestige and professional mobility.

These objectives are addressed in the following discussion of issues:

\subsection{Principle and Establishment of a Statutory Framework for the Civil Service}

10.1.1. The need for simple rules which can be immediately applied is universally recognised and all four of the countries studied have adopted a statutory framework for the civil service.

However, while the adoption of such legislation can provide an invaluable legal framework (definition of the scope of the civil service, rules for recruitment and career management, etc.), it would seem equally important for these rules laid down by law to be recognised and accepted by all the parties concerned and to be transformed into management practices.

Furthermore, the discussion cannot be limited solely to those public officials who have the legal status of civil servants, the proportion of which varies widely from one country to another. The professionalism and performance of all the staff in ministries and subsidiary agencies (to remain within the framework of the present study) also need to be closely examined, regardless of the legal status of the personnel concerned.

10.1.2. In general, it is possible to identify several types of functions and levels of responsibility which vary significantly in importance from one country to another. In each case, drawing the dividing line between different categories is by no means straightforward and must take account of the distinctive characteristics of the country considered:

- Posts of a political nature or providing support for functions relating directly to the office of the minister may be identified as government offices. It would seem logical that those persons appointed to such posts do not fall within the civil service, given that their role is to carry out a series of functions entrusted to them by the political authorities. 
- Posts which entail decision-making responsibilities, the formulation and definition of public policies, together with steering or supervisory tasks, may be made subject to the statutory framework of the civil service, if such a framework exists. This type of post calls for special qualifications and neutrality, which it would be worthwhile to define and protect by law. It would be worthwhile to remove a certain number of specific functions, such as those involved in fiscal administration, completely from the civil service framework. It is also at this level that the need is the most evident for qualified and motivated senior officials, for whom the private sector is particularly attractive.

- Posts involving administrative and executionary tasks could conceivably either have civil service status or be covered by collective agreements and the labour code, provided that the legislation specifies precisely where the boundary lies between these two categories.

- Posts relating to particular functions, such as police, justice or armed forces, are covered by specific statutes.

\subsection{Design and Implementation of a Personnel Policy}

10.2.1. In the course of the transition period, the overall mandates of individual administrations have evolved considerably. New tasks have emerged, such as preparation for European integration, while others have become less important. Although reorganisations, sometimes accompanied by dismissals, have been carried out in some sectors, the need to meet immediate requirements has in most cases precluded an overall review of the allocation of human resources and the matching of such resources to the tasks to be performed. Such a review would require a fairly detailed survey of the number of officials employed by each department, together with personal details (age, level of education, experience, etc.). The aim is not only to demonstrate the chronic lack of resources, which administrations are the first to denounce, but also to carry out a qualitative assessment of the use made of existing resources in relation to the task to be carried out in each department. It is a question of enlightening the decision-making process by avoiding arbitrary or standardised reductions in staff without any consideration of real needs and by permitting the necessary redeployment of personnel.

10.2.2. There would seem to be a correlation between the weak harmonisation of personnel management policies and the problems encountered in the setting up of a professional civil service. It is true that personnel managers are able to derive immediate benefits from the leeway and flexibility provided by their autonomy in recruitment and, in particular, remuneration. It is also true that this freedom allows some managers to experiment and to develop innovative personnel management policies, which subsequently serve as lessons of benefit to other ministries. It would seem, however, that the lack of a co-ordinating, advisory and implementing body has an adverse impact on career management in that it could undermine the efforts made to make the civil service both more professional and more efficient.

While co-ordination is not an end in itself (a poorly designed co-ordinating system might even make procedures more cumbersome), a minimum level of co-ordination could nonetheless bring improvements and, in particular, help to prevent conflicting regulations or policies from being introduced by individual ministries for reasons of corporatist or other ties. This does not mean that centralised management of staff should be within a single governmental authority. On the other hand, such co-ordination could include the implementation of priorities set at the national level, the matching of resources to objectives and the monitoring of personnel management.

10.2.3. The question remains open as to what would be the most effective means of developing such co-ordination, and responses would undoubtedly vary from one country to another. In this area efficiency 
must be tempered with realism. Experience shows that setting up bodies with functions that are either too ambitious or poorly defined is a factor of failure. However, co-ordination can achieve progress in areas where it is entrusted to a body with precise and realistic tasks commensurate with its allocated resources. It would seem that setting up a simple structure within an institution invested with sufficient authority (the Prime Minister's office, Ministry of Finance, Ministry of the Interior, Ministry of Labour, Civil Service Ministry, or other) can play a positive role in encouraging ministries to pursue harmonised and coherent policies. It would be advisable to clearly identify and realistically formulate the functions of such a body.

\subsection{Instruments of a Personnel Policy}

What instruments can a personnel policy rely on? A number of observations made in the course of this study may provide some initial answers to this question.

10.3.1. Irrespective of the role given to the co-ordinating body, the role of the personnel directorates within each ministry is crucial. When such directorates are given the authority, stability and resources required to exercise their functions, human resources are managed with greater rigour and the influence of political factors or personal networks is significantly reduced. It is also useful if personnel policies are understood and accepted by all concerned officials, and activities of awareness and training could be organised for this purpose.

10.3.2. One instrument to harmonise management and compliance rules consists of the creation of a single staff register, for which provision has been made in the 1996 Decree in Albania and which is already current practice in Hungary (personnel register) as well as in many western European countries. Such an instrument also enables the co-ordinating body to monitor all management decisions and to ensure that human resource policies adopted at the national level are followed. Several types of management can be envisaged, depending on methods of organisation and division of powers between ministries, on the one hand, and the development of computer resources on the other. Computerised management is the most functional method, as the creation of a network makes it possible to share the register. However, in cases where the computer-based system is not feasible immediately, personnel files can be managed manually in a first stage in preparation for the passage to computerised management.

10.3.3. Providing information on the rules governing post and career management, in cases where this is done, may be viewed as a highly positive measure, making it possible to attract larger numbers of applicants and to increase the motivation of officials. One aspect of this information is the publication of vacancy notices, which contributes substantially to the improvement of recruitment exercises (see below).

10.3.4. Although the issue has not been dealt with directly, the occasional gap observed between theory and practice raises the issue of controls. Failure to comply with regulations could be due to shortcomings in existing mechanisms.

Controls may be either jurisdictional or non-jurisdictional (administrative). Non-jurisdictional controls, which are used as a preventive measure, may take several forms. Thus verification of compliance with financial regulations constitutes an effective instrument on a day-to-day basis in order to cancel decisions which do not comply with the legislative and regulatory provisions in force. Any decision which has budgetary implications, even if taken at the highest level, therefore implies the explicit approval of a competent financial control authority appointed by the ministry of finance and attached to each public administration; unless such approval is granted, the decision may remain blocked. Other types of administrative control institutions may also be involved (commissions, inspectorates, etc.). 
Judicial control may be applied by specialised or non-specialised courts. A preliminary stage might consist of the creation of administrative appeals courts at ministerial or other levels. These courts, possibly made up of representatives of both the staff and the administration, could be responsible for examining appeals against decisions taken by management.

Such controls, simply by being in place, not only help to reinforce the rule of law but also serve to increase the confidence and motivation of officials with regard to their career and to improve the image of the administration.

\subsection{Recruitment}

Recruitment is a crucially important issue. It determines in fact the future of the administration through the renewal of generations of staff. The stakes are important as the recruitment of unsuitable officials runs the risk of restricting for many years the opportunities for putting in place a civil service that is both efficient and credible in the eyes of private sector and foreign partners.

Particular attention would apparently need to be given to certain elements which affect both the neutrality and the attractiveness of the administration: firstly, the provision of information on procedures and job descriptions; secondly, the choice of selection methods.

10.4.1. Providing information to the public is one of the key factors in establishing the rule of law and in ensuring the neutrality of the administration. However, transparency with regard to recruitment methods and criteria also contributes to the professionalism of the public service: by offering to the greatest number of people - particularly those with the required qualifications - the opportunity to prepare for and apply for posts subject to recruitment in the future, the administration increases the selectiveness of such recruitment exercises.

The provision of information concerns first of all the level of applicable rules: the conditions which candidates must meet (in terms of age, degree, etc.), the precise methods and criteria for selection in terms of the type of post to be filled, assignment procedures and content of the vacant post (it is the aim of the job description to match the qualifications required and the duties to be performed), salary level, career prospects. In a more global way, the respect of equity and equality between candidates also contributes to improving recruitment conditions.

10.4.2. The choice of recruitment methods varies according to circumstances and no method may be considered as intrinsically superior to another. It all depends on the number of potential candidates, the type of post to be filled, and the type of qualifications required. The procedure of open competition could therefore be adapted depending on the expected number of candidates so as to avoid too complicated arrangements.

The main pitfalls to avoid in this area are excessive formalism or, on the contrary, a total absence of rules. As this report has shown, a complex and sophisticated system is often inapplicable and discourages both managers and candidates. In contrast, the absence of a minimum number of rules generates suspicion, either rightly or wrongly, and casts doubt on the choices made. It is therefore advisable to seek an intermediate path, not as a bureaucratic solution but as a managerial approach to meet the basic requirements for a given post or type of post. For example, an approach conceived in terms of functional category (by type of profession) is more realistic than a system based on detailed descriptions of each job (it is significant that most Western countries have abandoned the systematic implementation of such a system). 


\subsection{Careers}

The professionalism and efficiency of the administration depend not only on the quality of recruitment, but also on the organisation of career development. Career prospects constitute in fact a determining factor in retaining the best officials in the civil service, and the recognition of their professional capacities through promotion represents a major incentive for improving their performance and qualifications.

The following points merit particular attention:

10.5.1. The establishment of a common framework applicable to different administrations and which sets a hierarchy of functions, grades and career development has a clarifying and harmonising effect. It makes it possible to avoid excessive disparities between sectors and places mobility in a positive light as a factor promoting integration within the civil service and providing mutual benefit to the administration and its officials.

10.5.2. Career development based on the principle of rewarding merit constitutes the central element for professionalising the civil service and motivating its officials. It is agreed that in order to reward merit, it is first necessary to put in place an evaluation system which makes it possible for decisions relating to career development to be based on a fair assessment of qualifications and performance, thereby ensuring the promotion of those officials whose competencies can be objectively recognised.

Such an evaluation system could draw upon the efforts which some countries have made in this area (United Kingdom, France, Germany, Hungary), which provide a few general lessons. Special attention could be given to the principle of establishing by means of regulations a set of objective criteria such as perseverance, punctuality, sociability, sense of responsibility, and ability to innovate, resolve problems at one's level and achieve departmental objectives, etc., which can be assessed by means of simple and transparent standards. These criteria might also be accompanied by quotas on the highest gradings in order to counter the natural tendency in any system to move rapidly towards a standardisation upwards. The introduction of an appraisal interview would, in addition, give the evaluator the opportunity to have direct contact with the official and thus gain a better understanding of the latter's ambitions and difficulties. Such an interview also represents, for the official being appraised, the best means of gaining a better understanding of what is expected of him/her in the future.

\subsection{Training}

It would be worthwhile to build upon the progress that has been made in the area of training by introducing an overall policy that takes account of both immediate requirements and longer-term needs. The experience of western European countries demonstrates the usefulness of a diagnostic approach based on the assessment of requirements and identification of objectives, within the framework of the priorities set at the national level through targeted programmes.

Particular attention might be given to the following points:

10.6.1. Matching the provision of training to the real needs of administrations might only require a fairly basic mechanism (consultation, surveys or other) to ensure a dialogue between those providing and

7. For further information on training systems, see SIGMA Papers: No. 16 - Public Service Training Systems in OECD Countries, August 1997. 
those requesting training. Preliminary efforts to explore the market and to plan for training might also help to achieve a better match between supply and demand for all categories of personnel.

10.6.2. The assessment of in-service training is an issue that most European countries are currently reviewing. It is unfortunately often the case that training is not sufficiently evaluated in terms of the real impact on trained officials as concerns the needs of the department. Efforts to remedy this situation are often strongly resisted by officials and by professional organisations, although such resistance can be overcome by consultation regarding objectives and training methods. Considering the growth of financial and human resources committed to such training, and the importance of the issues at stake, further consideration should be given to these matters in the years to come. The possibility that training of officials might be taken into account for their advancement, for example, represents a forceful argument in favour of adopting the principle of assessing training in terms of its content and actual impact on the qualifications and know-how of the officials concerned.

\subsection{Remuneration}

The different approaches to be considered in terms of career development might also extend to the subject of remuneration, for which the establishment of standard rules could be combined with a certain degree of flexibility, which would make it possible to adapt to specific circumstances and notably to the situation in the labour market. Two issues familiar to Western countries are currently the subject of debate.

10.7.1. Should salaries and bonuses be determined according to purely static criteria (grade, seniority, etc.) without taking any account of the individual merit of the official, his motivation and his achievements, or should a small percentage of remuneration based on merit be introduced in order to motivate those concerned?

10.7.2. How can the distribution of salary supplements be made more transparent? While this might appear desirable in principle, the obstacles to achieving this in practice are well known.

\subsection{Professional Ethics}

On the subject of professional ethics, a cautious and pragmatic approach needs to be adopted in drawing any lessons from the experiences of the four countries studied. Regulations that are too sophisticated have proved to be ineffective. The vacuum left by the collapse of the communist regime cannot be filled too abruptly or in too authoritarian a manner. The establishment of a code of ethics entails a lengthy learning process and the internalisation of standards by everyone involved. If established rules are to be obeyed, compliance must be in the interest of department heads or at any rate must not affect them adversely. It is also worth noting that the availability of personnel management tools determines whether rules are complied with in practice.

A system of sanctions, but especially a firm resolve to implement such sanctions, is essential. In fact, once a rule has been laid down, its infringement should be dealt with by disciplinary bodies or courts. There is no need for a complex array of control measures or sanctions in this area, and indeed such measures might even produce the opposite effect to the one sought. On the other hand, the certitude that infringement of the rules will be sanctioned can act as a major deterrent.

In this area, raising awareness is a useful preliminary to changing mentalities and habits, both of which must be accompanied by incentives, with sanctions being used only as a last resort. In the same way, 
behaviour in dealing with the public should be viewed as a learning process and a cultural issue rather than a code of conduct.

The case of pluralism is only one example of the type of dilemma faced by: should stringent rules be introduced or, on the contrary, should the exercise of some secondary activities be authorised to encourage officials to remain in the civil service, which would then pose the problem of establishing the boundary beyond which the public interest might be compromised? No solution can be automatically rejected, although any potential solution must be based on a careful examination aimed at establishing a dividing line between authorised secondary activities and those which might jeopardise the neutrality and impartiality of the public service.

In conclusion, it would seem that most administrative systems have one major characteristic in common: the problem of matching legislative texts with practices, and the need to narrow the gap between the two in order to ensure that the administration, and more generally the rule of law, functions properly.

As we have seen in the four studies, this problem is one which the countries of Central and Eastern Europe now find themselves facing, and in cases it requires urgent attention. Some of these countries have created sophisticated legislative and regulatory mechanisms which may prove difficult to apply. Others are marked by a culture and practices which are still far removed from the formal rigour which is provided by the legislative texts. It might be possible to align practices with legislative texts by taking steps to simplify standards and procedures so as to bring them more into line with practical necessities. At the same time, practices must be modified in order to secure greater compliance with the law by eliminating any risk of abuse or slippage which, over time, might threaten to corrupt the entire administrative system.

Such reforms, notably in Central and Eastern Europe, will stand a greater chance of success if efforts can be successfully combined and, in particular, if there is:

- a clear and continuous political resolve, expressed at the highest level, to ensure that the initial project does not lose momentum;

- widespread involvement of public officials at all levels of the hierarchy, in order to reduce the risk of misunderstanding or resistance to change;

- support from the public, as reforms will be more willingly accepted if the public feels that, in more or less the long term, it will benefit from them;

- assistance from the international community and from multilateral and bilateral co-operation organisations, whose ability to provide intellectual and material support for the reforms will be even greater if the objectives and means of achieving those objectives have been clearly defined. 


\section{ANNEX 1. GUIDELINE DOCUMENT}

\section{General Framework}

1.1. When a civil service law does exist:

Can you define its real scope: all public employees?

- including senior civil servants and political advisors?

- local civil servants?

- teachers, police, judges, ...?

- economic sectors (when not privatised) such as post, telephone, electricity, railway?

Has the law been modified since it was passed? How many times?

1.2. When a civil service law does not exist: are there any specific public regulations in the labour code or elsewhere for special groups of state employees?

1.3. To what extent is the legislation (civil service law / labour code / public regulations) applied or not applied? Could you give concrete examples of the practices in the following fields as well as the regulation defining the practice:

- recruitment and selection;

- evaluation of performance;

- mobility;

- neutrality;

- rights and duties;

- disciplinary procedure;

- pay system;

- (ethics).

1.4. Are the conditions of employment uniform throughout the public service (status, rights and duties, career, remuneration, etc.)? In theory? In practice?

What has to be closely examined is:

- how much the law (or regulation) goes into detail and how much discretion is left to public authorities;

- in which cases are legal or regulatory provisions not implemented and why;

- what are the main, if any, undesired effects of those provisions. 
1.5. Are data on public employees available?

- total number of state and local government officials;

- ratio public employees / inhabitants;

- ratio public employees / total workforce;

- distribution of public employees between ministerial departments;

- educational background (teachers, engineers, military) and diplomas;

- age and average length of service of current employees:

$\Rightarrow$ What proportion of employees recruited before transition are still in office?

$\Rightarrow$ What proportion will retire within the next five years? next 10 years?

- number of departures from the public sector during the past five years:

$\Rightarrow$ Have they increased? Why?

$\Rightarrow$ Where are they going (private sector, state-owned companies, politics)?

$\Rightarrow$ What is the turnover rate?

- the proportion of women at different levels.

\section{Personnel Management Organisation and Distribution of Powers}

2.1. On what level or regulated by which institution is personnel management regulated? If there is a central coordinating body, what are its functions (proposal, information, coordination, ...)? What is its real influence on major ministries (such as interior or finance)? Give examples.

2.2. What is the degree of autonomy (in theory and in practice) for each ministerial department in the management of its human resources and in the implementation of laws and regulations?

2.3. What is the distribution of powers and responsibilities within the departments? Who really takes the decisions in:

- recruitment;

- promotions;

- sanctions;

- payments.

How many people were hired last year:

- by advertisement?

- by recommendation?

Were they hired by the human resources department? With or without consultant services?

2.4. What are the main criteria for each kind of decision (education, performance, age, favouritism, political activity, family connection, etc.)? 


\section{Recruitment and Selection}

3.1. What are the recruitment procedures?

$\Rightarrow>$ Is the advertisement of vacancies organised? How?

=> Is recruitment organised for a large number of vacancies or for only a few?

$\Rightarrow>$ Is recruitment left to the discretion of the head of department or is it organised on the basis of competition, interview?

$\Rightarrow$ What are the real criteria for recruitment (education, favouritism, etc.)? Is there any difference between the formal and real systems of recruitment?

$\Rightarrow$ When the selection is based on competition. is an academic or practical examination organised?

=> Are job descriptions established? by whom?

What is meant by the term "job description" (main elements? length?)? Give examples.

How valid are they? How are they used?

3.2. Is there a probationary period? Is it purely formal or not?

3.3. Can the criteria of recruitment (diplomas, professional experience, etc.) be adapted to specific levels of the administrative hierarchy?

3.4. How competitive is recruitment in reality? How many candidates are there for one post (on average)?

This question should be examined in detail, for different departments and levels, and the reasons for the lack of candidates in various sectors should be identified.

$=>$ What means have been utilised by public authorities to make up for the lack of candidates? Did they succeed?

$\Rightarrow$ What would make the state administration more attractive to candidates? Higher salaries, bonuses? More attractive careers (promotion, mobility, access to responsibilities)? More interesting tasks? Other advantages?

3.5. What changes in recruitment and selection procedures have occurred since the transition? In theory? In practice?

\section{Training}

4.1. Can you describe the cultural context and social mechanisms that have a significant impact on education and values in the society (individual or collective values, impact of religious background, consideration for the rule of law, for efficiency, initiative or enterprise culture, etc.)?

4.2. Is there training for new recruits? Is it organised within ministries? Is it compulsory? Is this training appropriate for those who are now entering the state administration? Describe the system for top officials, intermediate employees, etc. 
4.3. What sort of in-service training is organised? Is it compulsory? Is it a condition for promotion?

If not, is there any other incentive for in-service training?

$\Rightarrow$ Who attends these courses in practice (officials who will have responsibilities or those one wants to get rid of?)

$\Rightarrow$ Are special courses organised for officials recruited before the transition? With what incentives?

4.4. What do the programmes deal with (law, management, economics, ethics, ...)?

How are the needs assessed? Are programmes established in accordance with needs?

4.5. What skills are lacking amongst public employees (at different levels of the hierarchy)?

How could the structure and functioning of the public employees' training system be improved?

5. Career

5.1. What constitutes grounds for dismissal or forced departure (restructuring, political reasons, inefficiency, offence)?

How many forced departures occurred last year? since the beginning of the transition?

5.2. Is there any possibility to recruit officials on a fixed-term contract basis? Is it implemented? What are the benefits (higher salaries, for example)?

Has there been any attempt since the transition to get rid of employees recruited before transition (through special examinations, pre-retirement, etc.)?

5.3. Is there any mobility between different ministerial departments? Within a single department? Are there any incentives for mobility?

Are there any attempts to evaluate the tasks and the number of public employees in different sectors, and to move redundant employees to other departments? What are the obstacles and difficulties?

5.4. What are the criteria for promotion? Merit, length of service, discretion of head of department? Who takes the decision?

Describe the promotion and performance appraisal system.

How and by whom is assessment organised? Is there any legislation or internal regulation to evaluate the performances of state employees? On what criteria? How is it implemented (in a formal way or as a real attempt to assess performance)?

6. Pay System (and other advantages)

6.1. Are the pay system and scale of salaries uniform throughout the public sector? If not, what are the differences?

6.2. How and by whom are the scale of salaries established and individual salaries determined? What are the criteria? 
6.3. What are the components of pay (direct salary, general or individual bonuses, discretionary allowances and rewards, different kinds of advantages such as apartments, foreign travel, etc., other income possibilities such as teaching, board membership in a state-owned company, etc.)? What are the proportions of the different components? How are allowances granted?

6.4. Give examples of state officials' salaries at different levels (including maximum and minimum). Give examples of comparisons with the private sector at different levels.

\section{Competition with the Private Sector}

7.1. Are many skilled officials leaving public administration for the private sector or state-owned companies?

$\Rightarrow$ Where are they going?

$\Rightarrow$ Which sectors are mainly concerned?

7.2. Could you enumerate some of the reasons for leaving public administration? Lack of prestige, lower salaries in civil service, more responsibilities or prestige in private sector? Other reasons?

What can be done to curb such a trend?

8. Accountability - Discipline

8.1. To which authority are civil servants accountable (head of state government, Parliament, courts)?

8.2. Can you describe the professional ethics? What are the common values and standards? What values are lacking? What could be done to improve the situation?

8.3. What are the main duties of public employees? Do they result from status, labour code, special regulations or orders from superiors? What are the rules about confidentiality and secrecy, obedience to the hierarchy, neutrality, loyalty, etc.? How can these principles be enforced?

8.4. Is a public official allowed to hold another job at the same time in the private or public sector? (or to do any other work?) Is it frequent in practice? What are the rules about conflict of interest? What are the social and legal sanctions (labour code provisions, criminal sanctions) in the case of conflict of interest?

8.5. What are the main rights of public employees (freedom of expression, right to strike or join a trade union, fair treatment upon dismissal, etc.)? What are the problems raised in practice?

8.6. Describe the disciplinary system (in theory and in practice) and the decision-making process. Is there any appeals system? Judicial review?

8.7. What are the main offences? Is it possible to dismiss public employees for inefficiency? Corruption? Does this really happen in practice? Can you give examples? 


\section{Relations with the Public}

9.1. Can you describe the relations with the public? Do public officials remain anonymous or are they required to state their names?

9.2. Are there instructions about courtesy, information, assistance to users? Are they implemented? Is there any attempt to introduce incentives in order to improve relations with the public?

9.3. What are the working hours in theory and in practice? What are the opening hours of the different services? Are they effective?

9.4. Can users make complaints about the behaviour of public employees? What are the legal recourses?

9.5. Is there secrecy legislation?

Is there a freedom of information act? (Why not?)

If there is freedom of information legislation, does it provide for an extensive right of access to documents? Does any other legislation provide for such a right or is the disclosure of documents left to the discretion of the administration? What kind of documents can be kept secret? What is the procedure for access to documents? Is this legislation implemented? What are the costs? What are the sanctions?

9.6. (What is the global appreciation of officials by users? What is regarded as a problem?)

\section{Trade Unions}

10.1. Are public employees members of trade unions? What is the proportion of participation of public employees in the trade union system?

10.2. Are trade unions entitled to participate in collective bargaining and in human resources management in state administration? To what degree? Is their role (both formal and informal) to provide or receive information, to be consulted, or to be included in the decision-making process?

10.3. Do you think that, in the near future, this role should be expanded, reduced or completely transformed?

\section{Influence of Human Resources Management on Public Administration}

11.1. Is the concept of management used within the administration? With what meaning (managerialism, discretionary powers, performance-related pay, reliance on private sector management and/or recruitment)?

11.2. Is there any political debate on this point? What are the recent reforms or projects? 


\section{Administration and Politics}

12.1. In what kind of political activities may public employees be involved?

Is it possible to be a member of a political party? To hold office in a party?

12.2. At what level can officials be dismissed or moved for political reasons? (how deep is politicisation?)

12.3. For other officials, what is the influence of politics on career (recruitment, promotion, pay)?

12.4. Do politicians command administrators or do administrators have the real power within the bureaucratic structure?

12.5. What are the relations between state officials and Parliament? Are there former members of Parliament within state administration? Does the Parliament exercise any kind of control over public administration (inquiries, etc.)? 